\title{
Metal Complexes of New Bioactive Pyrazolone Phenylhydrazones; Crystal Structure of 4-Acetyl-3-methyl-1-phenyl-2-pyrazoline-5-one phenylhydrazone Ampp-Ph
}

\author{
Omoruyi G. Idemudia ${ }^{1, *}$, Alexander P. Sadimenko ${ }^{1}$ and Eric C. Hosten ${ }^{2}$ \\ 1 Chemistry Department, University of Fort Hare, Private Bag X1314, Alice 5700, South Africa; \\ asadimenko@ufh.ac.za \\ 2 Chemistry Department, Nelson Mandela Metropolitan University, Summerstrand Campus, P.O Box 77000, \\ Port Elizabeth 6031, South Africa; eric.hosten@nmmu.ac.za \\ * Correspondence: Oidemudia@ufh.ac.za; Tel.: +27-786-273-150
}

Academic Editors: Sotiris Hadjikakou and Nick Hadjiliadis

Received: 27 March 2016; Accepted: 22 April 2016; Published: 18 May 2016

\begin{abstract}
The condensation reaction of phenylhydrazine and dinitrophenylhydrazine with 4-acetyl and 4-benzoyl pyrazolone precipitated air-stable acetyldinitrophenylhydrazone Ampp-Dh, benzoylphenylhydrazone Bmpp-Ph and benzoyldinitrophenylhydrazone Bmpp-Dh in their keto imine form; a study inspired by the burning interest for the development of new bioactive materials with novel properties that may become alternative therapeutic agents. Elemental analysis, FTIR, ${ }^{1} \mathrm{H}$, and ${ }^{13} \mathrm{C}$ NMR, and mass spectroscopy have been used to justify their proposed chemical structures, which were in agreement with the single crystal structure of Bmpp-Dh earlier reported according to X-ray crystallography. The single crystal structure of 4-acetyl-3-methyl-1-phenyl-pyrazoline-5-one phenylhydrazone Ampp-Ph, which crystallizes in a triclinic crystal system with a P-1 (No. 2) space group is presented. Octahedral $\mathrm{Mn}(\mathrm{II}), \mathrm{Ni}(\mathrm{II}), \mathrm{Co}(\mathrm{II})$, and $\mathrm{Cu}(\mathrm{II})$ complexes of these respective ligands with two molecules each of the bidentate Schiff base, coordinating to the metal ion through the azomethine nitrogen $\mathrm{C}=\mathrm{N}$ and the keto oxygen $\mathrm{C}=\mathrm{O}$, which were afforded by the reaction of aqueous solutions of the corresponding metal salts with the ligands are also reported. Their identity and proposed structures were according to elemental analysis, FTIR spectroscopy, UV-VIS spectrophotometry (electronic spectra) and Bohr magnetic moments, as well as thermogravimetric analysis (TGA) results. A look at the antibacterial and antioxidant activities of synthesized compounds using the methods of the disc diffusion against some selected bacterial isolates and 1,1-diphenyl-2-picryl-hydrazil (DPPH) respectively, showed biological activities in relation to employed standard medicinal drugs.
\end{abstract}

Keywords: phenylhydrazide; dinitrophenylhydrazone; acylpyrazolone; transition metal complexes; TG-DTG; X-ray crystallography; biological studies

\section{Introduction}

Schiff bases can be said to be one of the most researched group of chemical molecules by scientists, the reasons being their versatility, selectivity, sensitivity, stability, and ease of synthesis, just to mention but a few, which have resulted in their wide applications [1-3]. In the midst of their well-researched bioactive medicinal and pharmacological applications [4-6], azomethines, as they are also called, either alone or by some sort of modification, have attracted uses as analytical reagents [7], catalysts [8,9], and as azo compounds for use as dyes and pigments [10]. They have also exhibited corrosion inhibition characters for mild steel in $\mathrm{H}_{2} \mathrm{SO}_{4}$ carried out at different temperatures and concentrations [11]; 
a property that have been attributed to their spatial arrangement and electronic structure [12,13]. It has been reported that the azomethine functional group which they possess contribute to their bioactivity [14], the azomethine nitrogen $\mathrm{C}=\mathrm{N}$ may interact and form intramolecular hydrogen bonding with some responding sites within the cell structure, which thus affects the regular cell processes; hence, their biological significance $[15,16]$. Similarly, the lone pair electron in the sp2 hybridized orbital of the azomethine nitrogen is another reason for their chemical reactivity. To a great extent the properties of the Schiff base metal complexes depend on the nature of the ligand and that of the metal ion; usually the Schiff base exhibits a certain electronic environment around a metal ion; therefore, their unique characteristics. 4-acylpyrazolones are di-ketone derivatives of pyrazolone, substituted at the position 4 of the pyrazole ring. Their tautomerism, an ability to exist either in enol or keto structural forms gives them the potential to form different types of interesting coordination compounds [17,18]. Due to their significant pharmacological and biological applications, acylyrazolones have become a more important class of heterocycles $[19,20]$, although their prototypes antipyrines have been synthesized and used as clinical drugs. They serve as useful precursors for the synthesis of superior and more chelating Schiff bases [21,22]. Dinitrophenylhydrazine is a nitro-substituted phenylhydrazine at positions 2 and 4 of its phenyl with the formula $\mathrm{C}_{6} \mathrm{H}_{6} \mathrm{~N}_{4} \mathrm{O}_{4}$. It is a reddish yellow compound (Figure 1), as reported by Brady and Elsmie, used as an analytical reagent for the quantitative identification of carbonyl functional groups [23]; a property that qualifies it as a good nucleophile for carbonyl aldehydes and ketones in the formation of Schiff bases. We have reported the single crystal structure of the first acylpyrazolone derivative of 2, 4 dinitrophenylhydrazone Bmpp-Dh [24] and that of phenylhydrazone Bmpp-Ph [21], and in continuation of our studies on the design of new metal ion chelating Schiff bases with new chemical properties, presented herein is the synthesis, spectroscopy, thermal, and biological studies of some new acylpyrazolone-based phenylhydrazones and their metal complexes.<smiles>NNc1ccccc1</smiles>

Phenylhydrazine

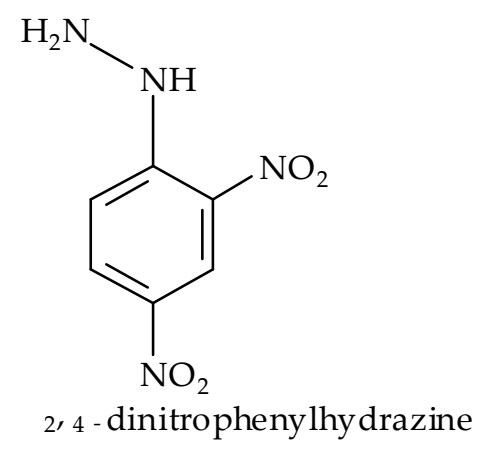

Figure 1. Phenylhydrazine derivatives.

\section{Results}

\subsection{Synthesis}

Acetyl and benzoyl pyrazolone Schiff base precursors were reacted with 2,4-dinitrophenylhydrazine and then with phenylhydrazine in two different one-pot synthesis setups, to afford the Schiff bases; 4-acetyl-3-methyl-1-phenyl-2-pyrazolin-5-one dinitrophenylhydrazone Ampp-Dh, 4-benzoyl3-methyl-1-phenyl-2-pyrazolin-5-one dinitrophenylhydrazone Bmpp-Dh, and 4-benzoyl-3-methyl-1phenyl-2-pyrazolin-5-one phenylhydrazone $\mathrm{Bmpp}-\mathrm{Ph}$, as shown in the synthesis scheme in Figure 2. We have previously reported the synthesis, characterization, and biological studies of 4-acetyl-3-methyl-1-phenyl-2-pyrazolin-5-one phenylhydrazone Ampp-Ph, as well as a suitable synthesis scheme [25]. 
<smiles>[R]C(=O)C1C(=O)N(c2ccccc2)N([R14]([R])([H])C([R])C)C1=O</smiles>

2, 4-dinitrophenylhydrazine

4-acyl-3-methyl-1-phenyl-2-pyrazolin-5-one

Ampp-Dh or Bmpp-Dh<smiles>CC1=NN(c2ccccc2)C(=O)C1/C(=N\Nc1ccc(C(O)O)cc1)c1ccccc1</smiles>

4-benzoyl-3-methyl-1-phenyl-2-pyrazolin-5-one

Bmpp-Ph

Figure 2. Synthesis scheme of phenylhydrazones.

The synthesized Schiff bases were in solid form and stable at room temperature. They are soluble in methanol, ethanol, and most common organic solvents. Schiff bases were precipitated in good yield and purity was confirmed by thin layer chromatography (TLC), which was corroborated by a small melting point range. A total of fourteen metal complexes were synthesized by the treatment of Ampp-Dh, Bmpp-Dh, Ampp-Ph, and Bmpp-Ph with the appropriate metal salt, presented in the synthesis scheme illustrated with an equation in Figure 3. The complexes are generally insoluble in water, ethanol, and in non-coordinating solvents. However, they were soluble in polar solvents with strong donor strength, like Dimethylformamide (DMF) and DMSO. Molar conductance values of metal complexes infer non-electrolyte behavior in DMF [26].

$$
\begin{gathered}
\mathrm{MX}_{2} \cdot \mathrm{nH}_{2} \mathrm{O}+2 \mathrm{~L} \frac{\mathrm{EtOH} / \mathrm{H}_{2} \mathrm{O}}{\operatorname{reflux} 4 \mathrm{~h}} \mathrm{M}(\mathrm{L})_{2}\left(\mathrm{H}_{2} \mathrm{O}\right)_{2} \cdot \mathrm{nH}_{2} \mathrm{O} \\
\mathrm{M}=\mathrm{Mn}^{2+}, \mathrm{Co}^{2+}, \mathrm{Ni}^{2+} \text { or } \mathrm{Cu}^{2+}, \mathrm{X}=\mathrm{Cl}^{-} \text {or } \mathrm{MeCOO}^{-} \\
\mathrm{L}=\text { Ampp-Dh, Bmpp-Dh or Bmpp-Ph }
\end{gathered}
$$

Figure 3. Synthesis scheme of phenylhydrazones metal complexes.

The percentage composition of CHN elemental analysis in Ampp-Dh, Bmpp-Dh, Bmpp-Ph and their metal complexes found, were in agreement with calculated values (refer to the experimental section). Octahedral metal complexes of the bidentate Schiff bases have been proposed. The complexes have two molecules of the bidentate Schiff base and two water molecules each to complete their octahedral geometry $[27,28]$. Some of their physical properties, melting point range, elemental composition, conductivity, and percentage yield are presented in the experimental section.

\section{2. ${ }^{1} \mathrm{H}$ and ${ }^{13} \mathrm{C}$ NMR Spectroscopy}

${ }^{1} \mathrm{H}$ and ${ }^{13} \mathrm{C}$ NMR spectroscopy of synthesized ligands in deuterated DMSO were carefully carried out, with trimethylsilane TMS as the internal standard in DMSO- $d_{6}$. Ampp-Dh (Figure 4) showed a singlet with a broad base integrating for one proton at $10.8 \mathrm{ppm}$ which is assigned to the $-\mathrm{NH}$ of the dinitrophenylhydrazine. This was followed by another singlet resonating at $8.8 \mathrm{ppm}$ which is due to hydrogen attached to the azomethine carbon atom $\mathrm{C}=\mathrm{NH}$. There is a weak signal at $2.4 \mathrm{ppm}$ which may be assigned to the methyl protons but its integration showed otherwise, the reason being that it 
has probably been unusually merged with the DMSO peak. However, the mass spectrum molecular peak and fragmentations, discussed in Section 2.3 below, corroborates the proposed composition and structure of Ampp-Dh in agreement with the reported crystal structure of a similar compound. The aromatic protons $\mathrm{H}-\mathrm{Ar}$ are observed as a multiplet at 8.4-7.2 ppm.

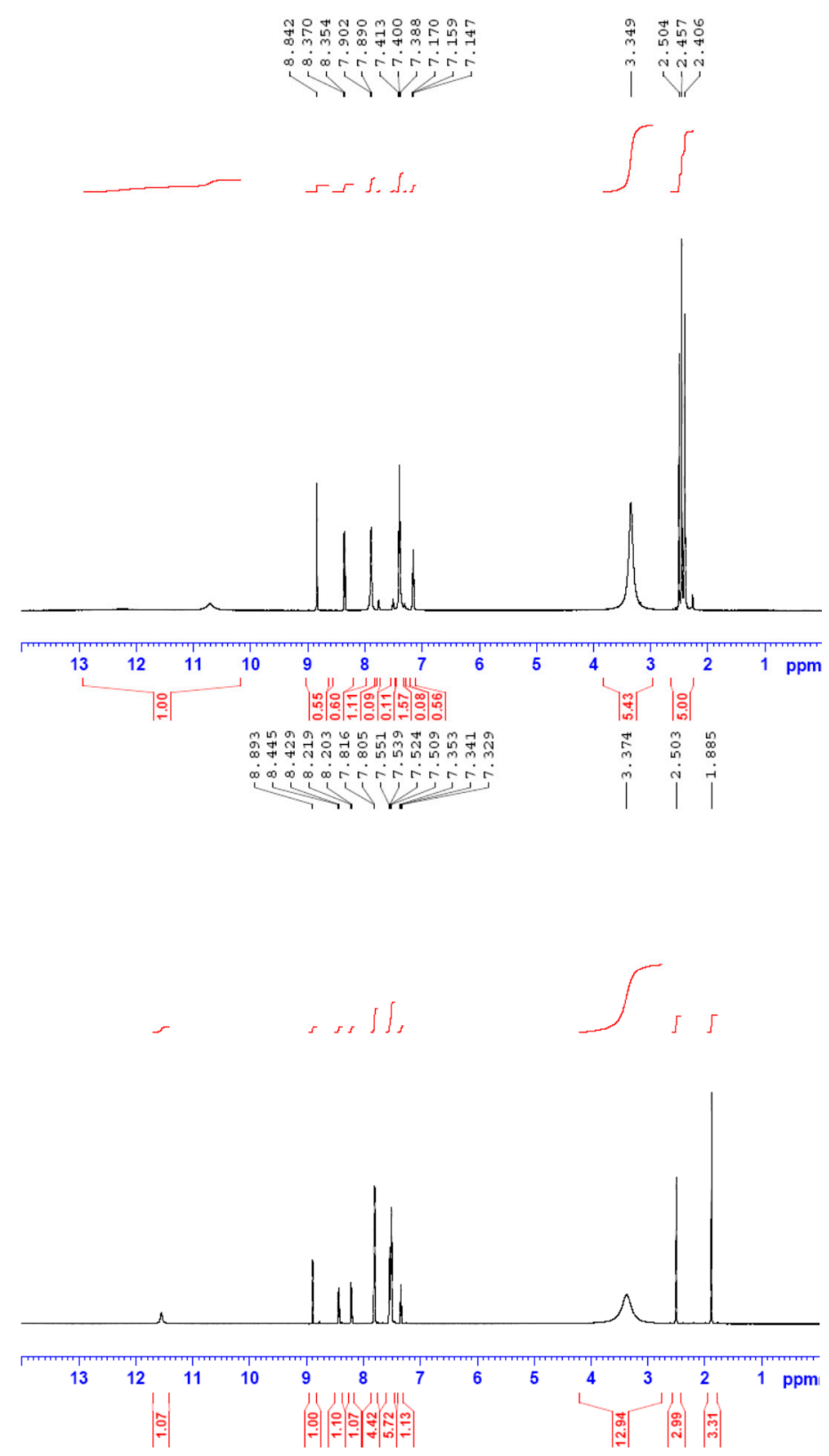

(I)

(II)

Figure 4. (I) ${ }^{1} \mathrm{H}$ NMR spectrum of Ampp-Dh; and (II) ${ }^{1} \mathrm{H}$ NMR spectrum of Bmpp-Dh.

In Bmpp-Dh, the $-\mathrm{NH}$ proton and that of the azomethine carbon atom $\mathrm{C}=\mathrm{NH}$, respectively, resonated in the downfield region with chemical shift at 11.6 and $8.9 \mathrm{ppm}$ integrating for one proton each. The multiplet, due to the aromatic hydrogens, was observed at $8.5-7.3 \mathrm{ppm}$, but the integrating protons are not equivalent, which may be due to the overlap of equivalent protons. Finally, the resonance peak due to methyl hydrogens was displayed as a sharp signal upfield of the NMR spectrum at $1.9 \mathrm{ppm}$ integrated for three hydrogen atoms as expected [28]. The ${ }^{1} \mathrm{H}$ NMR spectroscopy of $\mathrm{Bmmp}-\mathrm{Ph}$ (Figure 5) showed similar trend as Bmpp-Dh. The aromatic protons $\mathrm{H}-\mathrm{Ar}$ were observed as a multiplet at $6.8-8.4 \mathrm{ppm}$ and the resonating peak in the aliphatic region with a chemical shift of 
$1.9 \mathrm{ppm}$ is due to the methyl protons attached to the pyrazolone ring integrating for approximately three protons. Two broad peaks resonating downfield at around 12.2 and $9.5 \mathrm{ppm}$ integrating for approximately one proton each are assigned to the hydrogen atoms of the $-\mathrm{NH}$ and the $\mathrm{C}=\mathrm{NH}$ azomethine group, respectively.

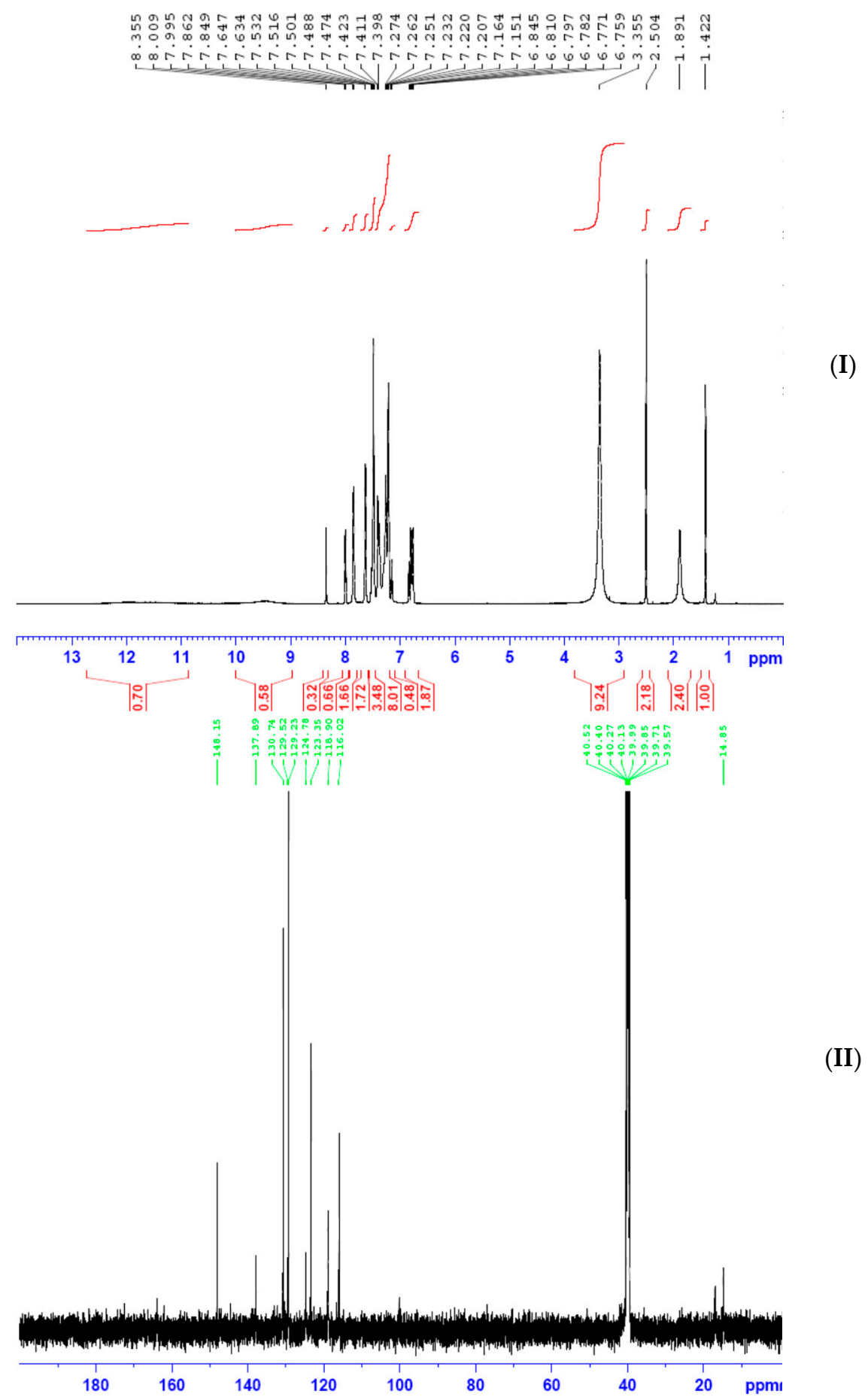

Figure 5. (I) ${ }^{1} \mathrm{H}$ NMR spectrum of Bmpp-Ph; and (II) ${ }^{13} \mathrm{C}$ NMR spectrum of Ampp-Dh.

${ }^{13} \mathrm{C}$ NMR spectra of Ampp-Dh, Bmpp-Dh, and Bmpp-Ph displayed aromatic carbon atoms at a chemical shift of 137.9-116.02, 144.6-117.2, and 148.0-115.3 ppm, respectively. Signals due to azomethine carbon $\mathrm{C}=\mathrm{N}$ and the pyrazolone carbonyl carbon $\mathrm{C}=\mathrm{O}$ are observed at 137.7 and 
at $146.2 \mathrm{ppm}$, respectively in Ampp-Dh [29]. The two methyl group carbons are observed at 16.2 and $14.9 \mathrm{ppm}$ assigned to the pyrazolone methyl and the acetyl methyl, respectively. In Bmpp-Dh, resonance bands due to $\mathrm{C}=\mathrm{N}$ and $\mathrm{C}=\mathrm{O}$ are seen at a chemical shift of 147.44 and $148.9 \mathrm{ppm}$, respectively (Figure 6). Finally, in Bmpp-Dh, the only methyl carbon appears as a single signal in the aliphatic region at $13.6 \mathrm{ppm}$.

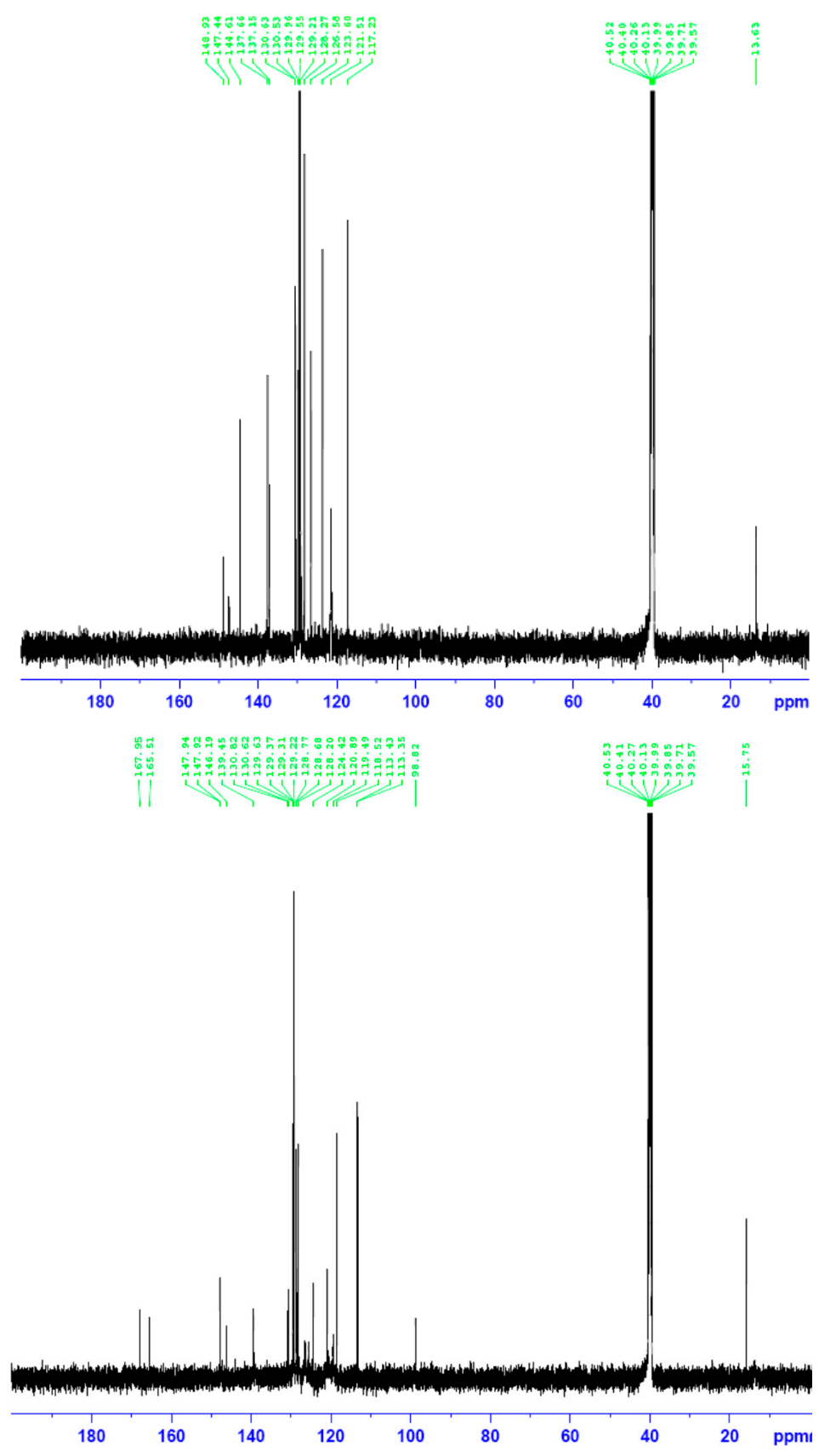

(I)

(II)

Figure 6. (I) ${ }^{13} \mathrm{C}$ NMR spectrum of Bmpp-Dh; and (II) ${ }^{13} \mathrm{C}$ NMR spectrum of Bmpp-Ph.

A signal due to pyrazolone methyl carbon resonates at $15.8 \mathrm{ppm}$ in the $\mathrm{Bmpp}-\mathrm{Ph}{ }^{13} \mathrm{C}$ NMR spectrum and the resonance signals at $168.0 \mathrm{ppm}$ may be assigned to the carbonyl carbon of the pyrazolone $\mathrm{C}=\mathrm{O}$. Additionally, the signal at $165.5 \mathrm{ppm}$ is due to the azomethine carbon atom $\mathrm{C}=\mathrm{N}$ [29] and the pyrazolone methyl carbon signal resonated at $15.8 \mathrm{ppm}$. 


\subsection{Mass Spectroscopy}

The prominent peaks at 100\% observed in the mass spectra of Ampp-Dh, Bmpp-Dh, and Bmpp-Ph correspond to the molecular ion $\mathrm{M}^{+}$at $m / z 397, m / z 459$, and $m / z 369$, respectively (Figure 7). The molecular ions observed in the Schiff base ligands confirm the calculated theoretical molar mass plus a proton $[\mathrm{M}+\mathrm{H}]^{+}$.

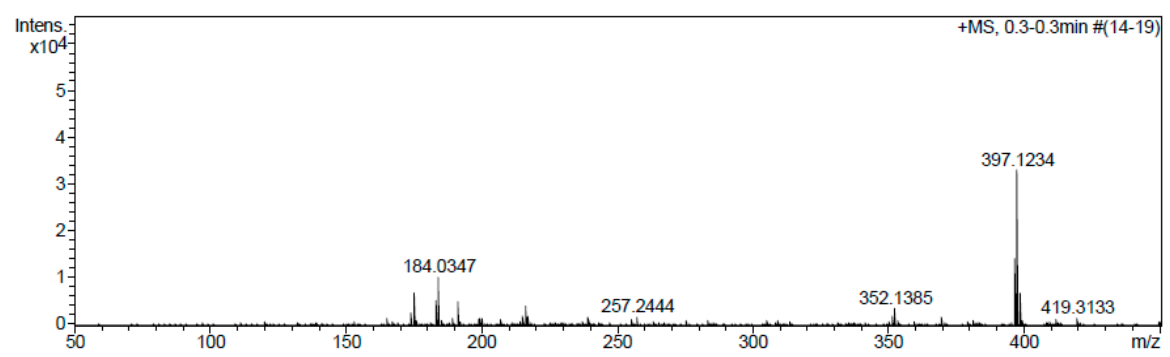

(I)

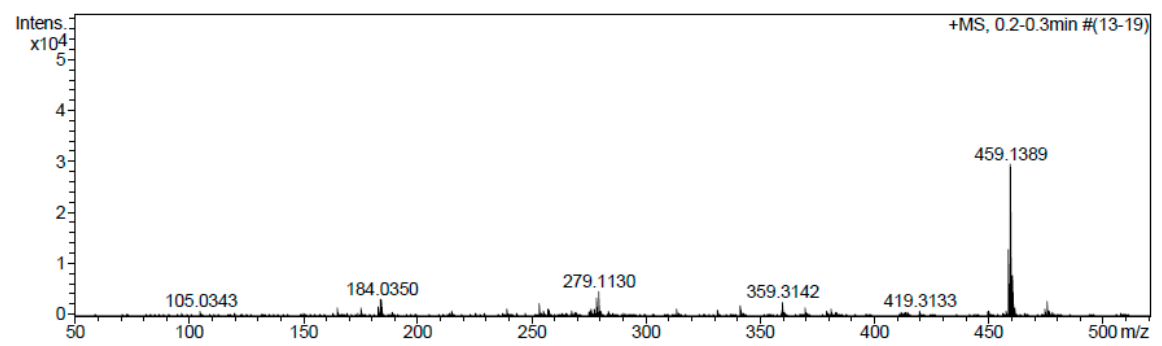

(II)

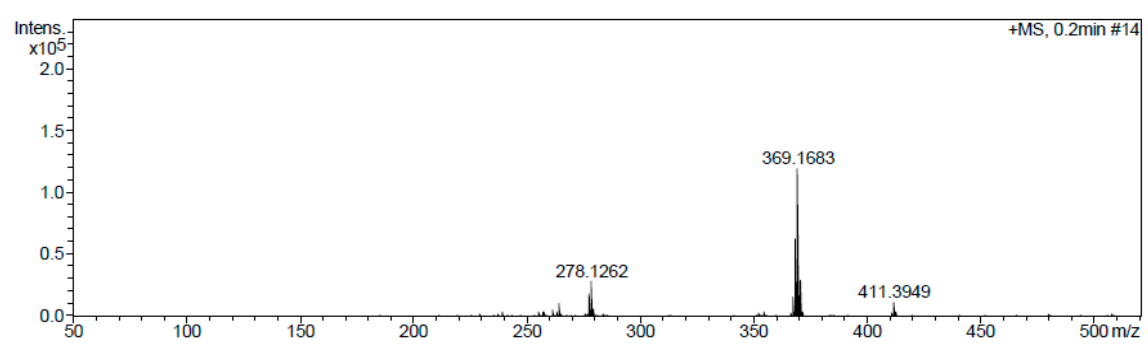

(III)

Figure 7. (I) Mass spectrum of Ampp-Dh; (II) mass spectrum of Bmpp-Dh; and (III) mass spectrum of Bmpp-Ph.

The peak at $m / z 279$ in Bmpp-Dh is due to the protonated benzoyl pyrazolone Schiff base precursor, $\mathrm{C}_{17} \mathrm{H}_{14} \mathrm{~N}_{2} \mathrm{O}_{2}$ fragmentation, which is observed at $\mathrm{m} / z 278$ in Bmpp-Ph but for an unprotonated Schiff base precursor.

\subsection{X-ray Crystallography}

The reported Ampp-Ph single crystal structure was obtained from a slow evaporation of its DMF solution. A summary of crystal information is presented in Table 1.

In the structure of Ampp-Ph, the phenyl on the dihydropyrazole group is turned slightly out of the dihydropyrazole least square plane by $24.90(5)^{\circ}$. The phenyl on the hydrazine group is turned out more and makes a least square dihedral angle of $84.64(3)^{\circ}$ with the dihydropyrazole plane (Figure 8).

There is one short intramolecular hydrogen bond N3-H3 ... O1 of length 1.931(15) A which, in terms of graph-set analysis [30,31], necessitates a $S^{1}{ }_{1}(6)$ descriptor on the unary level. Adjacent molecules have two N4-H4 .. . O1 intermolecular hydrogen bonds of lengths 2.169(15) $\AA$ that have a $\mathrm{R}^{2}{ }_{2}(14)$ descriptor on the unary level. The $\mathrm{C} 26-\mathrm{H} 26$ bond has an intermolecular $\pi$ ring interaction with a C11-C16 phenyl group with a hydrogen to centroid distance of $2.75 \AA$. The shortest $\pi$ ring interaction is between adjacent intermolecular C21-C26 phenyl rings with a centroid-to-centroid distance of 3.7827(7) $\AA$ and a slippage of $1.474 \AA$. 
Table 1. Crystal data for Ampp-Ph.

\begin{tabular}{cc}
\hline Compound & Ampp-Ph \\
\hline Formula & $\mathrm{C}_{18} \mathrm{H}_{18} \mathrm{~N}_{4} \mathrm{O}$ \\
Crystal colour and form & Golden yellow/Block \\
Formula weight & 306.36 \\
Crystal system & Triclinic \\
Space group & $\mathrm{P}-1$ \\
$a$ & $8.7006(5)(\AA)$ \\
$b$ & $9.6088(5)(\AA)$ \\
$c$ & $9.9124(5)(\AA)$ \\
$\alpha$ & $104.740(2)^{\circ}$ \\
$\beta$ & $96.360(2)^{\circ}$ \\
$\gamma$ & $103.196(2)^{\circ}$ \\
$V$ & $767.62(7)\left(\AA^{3}\right)$ \\
$Z$ & 2 \\
$D_{(\text {calc })}$ & $1.326\left(\mathrm{Mg} \mathrm{cm}{ }^{-1}\right)$ \\
$F(000)$ & 324 \\
$\theta$ range & $2.2-28.3\left({ }^{\circ}\right)$ \\
Crystal size & $0.47 \times 0.53(\mathrm{~mm})$ \\
$R$ & 20,159 \\
$w R_{2}$ & 0.0378 \\
$S$ & 0.1078 \\
Total Reflection measured & 1.02 \\
Temperature & $3801 / 3374$ \\
Parameters & $0.71073(/ \mathrm{mm})$ \\
Independent/observed & $200(\mathrm{~K})$ \\
& 218 \\
\hline
\end{tabular}

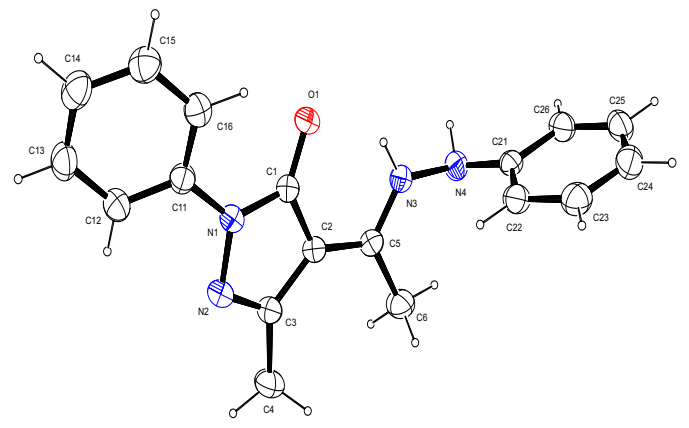

(I)

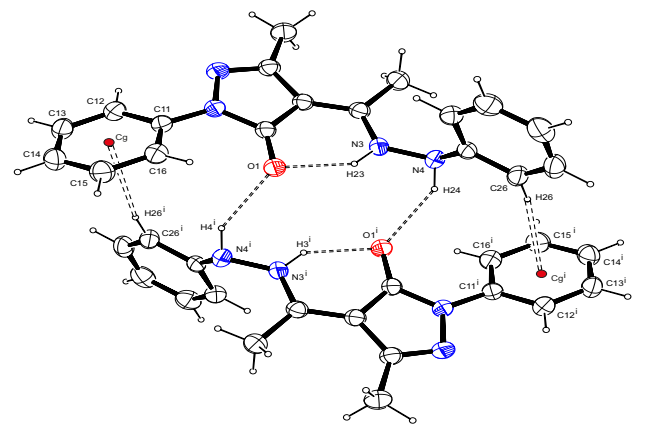

(II)

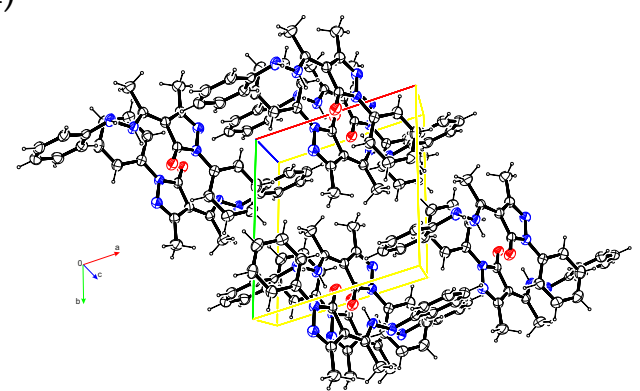

(III)

Figure 8. X-ray crystal structures: (I) Ortep diagram of the titled compound with thermal ellipsoids drawn at $50 \%$ probability level; (II) hydrogen interactions; for clarity the $\pi \ldots \pi$ ring interaction is not shown. $\mathrm{Cg}$ is the centroid of the C11-C16 phenyl group, Symmetry element (i) 1-x, -y, 1-z; and (III) packing diagram of Ampp-Ph. The coloured lines are the unit cell axis orientation and the red and blue circles represent oxygen and nitrogen respectively. 


\subsection{Infrared Spectroscopy}

The FTIR spectra of the azomethine ligands and their metal complexes were closely compared and the modifications in frequency vibration due to the interaction of the metal ion with the ligands were recorded. Octahedral complexes of the synthesized acylpyrazolone ligands have been proposed, which were in accordance with previously reported $[27,28]$. Ampp-Dh, Bmpp-Dh, and Bmpp-Ph exist in keto tautomer form, with FTIR spectra having a strong band vibrating at 1627, 1642, and $1634 \mathrm{~cm}^{-1}$, respectively, corresponding to the azomethine $v(\mathrm{C}=\mathrm{N})$. In the metal complexes, the metal ion coordinates through the donor nitrogen of the ligands azomethine group and based on this, the azomethine vibration in the FTIR spectra of metals complexes are observed at a lower wavenumber in the range of $1620-1617 \mathrm{~cm}^{-1}$ [32]. The broad band at $3486 \mathrm{~cm}^{-1}$ in Ampp-Dh, $3489 \mathrm{~cm}^{-1}$ in Bmpp-Dh, and at $3491 \mathrm{~cm}^{-1}$ in Bmpp-Ph, due to inter and intramolecular hydrogen bonding of the $v(\mathrm{~N}-\mathrm{H})$ stretching frequency was observed in the wave number range of $3481-3384 \mathrm{~cm}^{-1}$ in the metal complexes, attributed to $v(\mathrm{~N}-\mathrm{H})$ and $v(\mathrm{O}-\mathrm{H})$ from the water molecules [33]. The ketone carbonyl $v(\mathrm{C}=\mathrm{O})$ group was observed at 1498, 1501, and $1501 \mathrm{~cm}^{-1}$ in Ampp-Dh, Bmpp-Dh, and Bmpp-Ph, respectively, which was absent in the FTIR spectra of the metal complexes by way of forming -C-O-M bonds, an evidence of the coordination of the metal ion through the oxygen of the carbonyl ketone [34]. The two coordinated water molecules that completed the proposed octahedral geometry of metal complexes can be corroborated with the existence of a new band at around $849-830 \mathrm{~cm}^{-1}$ [33]. New bands at around $633-620 \mathrm{~cm}^{-1}$ and $492-478 \mathrm{~cm}^{-1}$ observed in the FTIR spectra of the transition metal complexes were assigned to the newly-formed $v(\mathrm{M}-\mathrm{N})$ and $v(\mathrm{M}-\mathrm{O})$ bonds, respectively [35].

\subsection{UV-VIS Spectroscopy and Magnetic Moments}

The ligands and their metal complexes showed absorption bands in the UV region due to $\pi \rightarrow \pi^{*}$ and $n \rightarrow \pi^{*}$ transitions [36]. The absorption bands displayed some modifications in the spectra of metal complexes as a result of metal ion coordination [37]. In general, the electronic spectra of most metal complexes reported exhibited unusual transitions but their magnetic moment values in Bohr Magneton (BM), agreed with theoretical predictions in line with established data. The energy values' closeness of different states of transitions may be the reason for the disappearance of some expected bands. Electronic spectra absorption bands and values in nanometers are displayed in the experimental section.

$\mathrm{Mn}$ (II) complexes of the titled acylpyrazolone-based phenylhydrazones show unusual electronic spectral bands in the visible region but close to the UV region. Two bands were observed at 436 and $462 \mathrm{~nm}$ in $\mathrm{Mn}(\mathrm{Bmpp}-\mathrm{Dh})_{2}\left(\mathrm{H}_{2} \mathrm{O}\right)_{2}$ and a band each at $451 \mathrm{~nm}$ in $\mathrm{Mn}(\mathrm{Ampp}-\mathrm{Dh})_{2}\left(\mathrm{H}_{2} \mathrm{O}\right)_{2} \cdot \mathrm{H}_{2} \mathrm{O}$ and $393 \mathrm{~nm}$ in $\mathrm{Mn}(\mathrm{Bmpp}-\mathrm{Ph})_{2}\left(\mathrm{H}_{2} \mathrm{O}\right)_{2} \cdot 2 \mathrm{H}_{2} \mathrm{O}$. These bands may be attributed to ${ }^{6} \mathrm{~A}_{1 \mathrm{~g}} \rightarrow{ }^{4} \mathrm{~A}_{1 \mathrm{~g}}$ transition a characteristic of an octahedral Mn(II) complex [38]. The magnetic moment of synthesized phenylhydrazone Schiff base complexes with $\mathrm{Mn}(\mathrm{II})$, which further justifies their geometry, were 5.65, 5.67, and 5.63 BM for Mn(Bmpp-Dh $)_{2}\left(\mathrm{H}_{2} \mathrm{O}\right)_{2}, \mathrm{Mn}(\mathrm{Ampp}-\mathrm{Dh})_{2}\left(\mathrm{H}_{2} \mathrm{O}\right)_{2} \cdot \mathrm{H}_{2} \mathrm{O}$, and $\mathrm{Mn}(\mathrm{Bmpp}-\mathrm{Ph})_{2}\left(\mathrm{H}_{2} \mathrm{O}\right)_{2} \cdot 2 \mathrm{H}_{2} \mathrm{O}$, respectively [39]. $\mathrm{Co}(\mathrm{Bmpp}-\mathrm{Dh})_{2}\left(\mathrm{H}_{2} \mathrm{O}\right)_{2} \cdot \mathrm{H}_{2} \mathrm{O}$ displayed bands at 425 and $460 \mathrm{~nm}$, and $\mathrm{Co}(\mathrm{Ampp}-\mathrm{Dh})_{2}\left(\mathrm{H}_{2} \mathrm{O}\right)_{2}$ showed a band at $414 \mathrm{~nm}$, followed by another one at $493 \mathrm{~nm}$, corresponding to $\left({ }^{4} \mathrm{~T}_{2 \mathrm{~g}} \rightarrow{ }^{4} \mathrm{~T}_{1 \mathrm{~g}}\right)$ and $\left({ }^{4} \mathrm{~A}_{2 \mathrm{~g}} \rightarrow{ }^{4} \mathrm{~T}_{1 \mathrm{~g}}\right)$ transition of an octahedral Co(II) complex, respectively. $\mathrm{Co}(\mathrm{Bmpp}-\mathrm{Ph})_{2}\left(\mathrm{H}_{2} \mathrm{O}\right)_{2} \cdot \mathrm{H}_{2} \mathrm{O}$ and $\mathrm{Co}(\mathrm{Ampp}-\mathrm{Ph})_{2}\left(\mathrm{H}_{2} \mathrm{O}\right)_{2} \cdot 2 \mathrm{H}_{2} \mathrm{O}$ exhibited similar transitions (Figure 9). $\mathrm{Co}(\mathrm{Bmpp}-\mathrm{Ph})_{2}\left(\mathrm{H}_{2} \mathrm{O}\right)_{2} \cdot \mathrm{H}_{2} \mathrm{O}$ showed a weak, broad, and almost unnoticeable band at $554 \mathrm{~nm}$, followed by a second band at $627 \mathrm{~nm}$ shoulder to a third band at $708 \mathrm{~nm}$. Three bands were also observed for $\mathrm{Co}(\mathrm{Ampp}-\mathrm{Ph})_{2}\left(\mathrm{H}_{2} \mathrm{O}\right)_{2} \cdot 2 \mathrm{H}_{2} \mathrm{O}$ in the visible region of its electronic spectrum at 390,536 , and $600 \mathrm{~nm}$ assigned to $\left({ }^{4} \mathrm{~T}_{2 \mathrm{~g}} \rightarrow{ }^{4} \mathrm{~T}_{1 \mathrm{~g}}\right),\left({ }^{4} \mathrm{~A}_{2 \mathrm{~g}} \rightarrow{ }^{4} \mathrm{~T}_{1 \mathrm{~g}}\right)$ and $\left({ }^{4} \mathrm{~T}_{1 \mathrm{~g}}(\mathrm{p}) \rightarrow{ }^{4} \mathrm{~T}_{1 \mathrm{~g}}\right)$ transitions, respectively. The measured magnetic moment for all four $\mathrm{Co}(\mathrm{II})$ complexes were between 4.45 and $4.48 \mathrm{BM}$, which were in agreement with the expected values for an octahedral $\mathrm{d}^{7} \mathrm{Co}(\mathrm{II})$ complex [40]. 


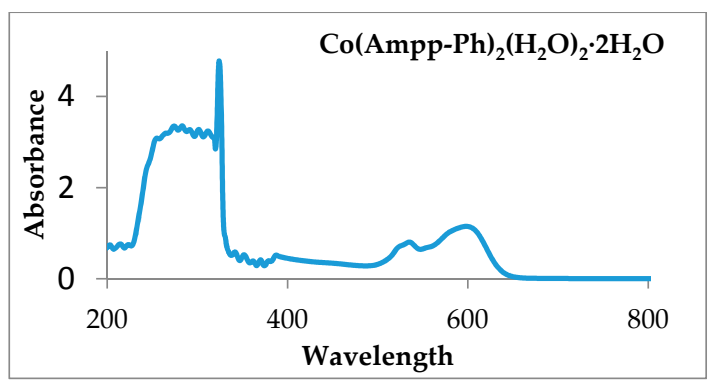

(I)

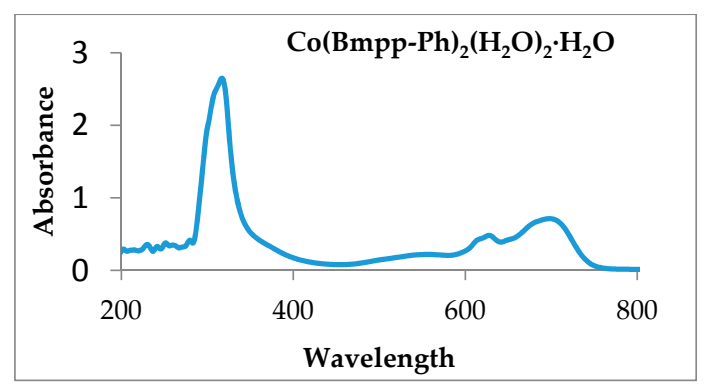

(II)

Figure 9. (I) Electronic spectra of $\mathrm{Co}(\mathrm{Ampp}-\mathrm{Ph})_{2}\left(\mathrm{H}_{2} \mathrm{O}\right)_{2} \cdot 2 \mathrm{H}_{2} \mathrm{O}$; and (II) electronic spectra of $\mathrm{Co}(\mathrm{Bmpp}-\mathrm{Ph})_{2}\left(\mathrm{H}_{2} \mathrm{O}\right)_{2} \cdot \mathrm{H}_{2} \mathrm{O}$.

The d-d absorption bands in $\mathrm{Ni}(\mathrm{Bmpp}-\mathrm{Dh})_{2}\left(\mathrm{H}_{2} \mathrm{O}\right)_{2} \cdot \mathrm{H}_{2} \mathrm{O}$ were observed at 431 and $463 \mathrm{~nm}$, and that of $\mathrm{Ni}(\mathrm{Ampp}-\mathrm{Dh})_{2}\left(\mathrm{H}_{2} \mathrm{O}\right)_{2}$ was seen as one band at $436 \mathrm{~nm}$. Two bands in the visible region were also observed in the $\mathrm{Ni}(\mathrm{Bmpp}-\mathrm{Ph})_{2}\left(\mathrm{H}_{2} \mathrm{O}\right)_{2} \cdot 2 \mathrm{H}_{2} \mathrm{O}$ spectrum at 678 and $808 \mathrm{~nm}$. These bands are assigned to ${ }^{3} \mathrm{~A}_{2 g} \rightarrow{ }^{3} \mathrm{~T}_{1 \mathrm{~g}}(\mathrm{~F})$ and ${ }^{3} \mathrm{~A}_{2 \mathrm{~g}} \rightarrow{ }^{3} \mathrm{~T}_{2 \mathrm{~g}}(\mathrm{~F})$ transitions for an octahedral $\mathrm{Ni}(\mathrm{II})$ complex. $\mathrm{Ni}(\mathrm{II})$ complexes reported herein have a magnetic moment value of between 2.90 and $2.98 \mathrm{BM}$ in further support of the proposed octahedral geometry around the nickel ion in agreement with reported data [41]. $\mathrm{Cu}(\mathrm{Bmpp}-\mathrm{Dh})_{2}\left(\mathrm{H}_{2} \mathrm{O}\right)_{2} \cdot 2 \mathrm{H}_{2} \mathrm{O}$ exhibited two bands at 425 and $460 \mathrm{~nm}$ corresponding to ${ }^{2} \mathrm{~B}_{1 \mathrm{~g}} \rightarrow{ }^{2} \mathrm{E}_{\mathrm{g}}$ transition associated with a magnetic moment of $1.95 \mathrm{BM}$. $\mathrm{Cu}(\mathrm{Ampp}-\mathrm{Dh})_{2}\left(\mathrm{H}_{2} \mathrm{O}\right)_{2}$ on the other hand, having a magnetic moment of $1.97 \mathrm{BM}$, shows a band at $467 \mathrm{~nm}$ attributed to ${ }^{2} \mathrm{~B}_{1 \mathrm{~g}} \rightarrow{ }^{2} \mathrm{E}_{\mathrm{g}}$ transition, and a broad band peculiar to a distorted octahedral $\mathrm{Cu}$ (II) complex at $598 \mathrm{~nm}$ corresponding to ${ }^{2} \mathrm{~B}_{1 \mathrm{~g}} \rightarrow{ }^{2} \mathrm{~B}_{2 \mathrm{~g}}$, Figure 10 .

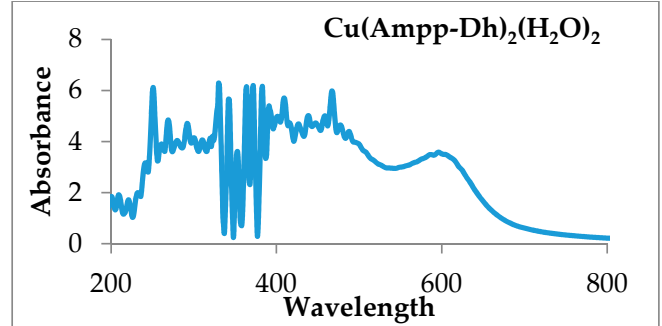

(I)

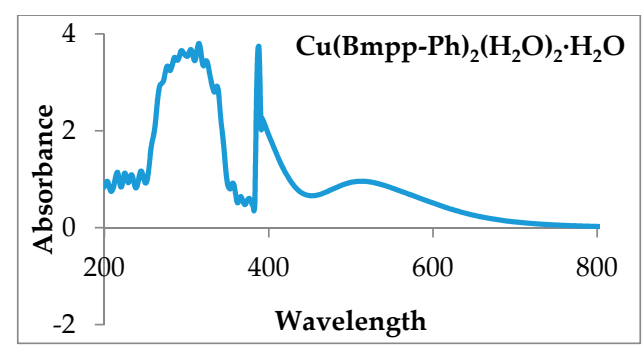

(II)

Figure 10. (I) Electronic spectra of $\mathrm{Cu}(\mathrm{Ampp}-\mathrm{Dh})_{2}\left(\mathrm{H}_{2} \mathrm{O}\right)_{2}$; and (II) electronic spectra of $\mathrm{Cu}(\mathrm{Bmpp}-\mathrm{Ph})_{2}\left(\mathrm{H}_{2} \mathrm{O}\right)_{2} \cdot \mathrm{H}_{2} \mathrm{O}$.

Additionally, a broad band corresponding to a distorted octahedral $\mathrm{Cu}(\mathrm{II})$ with a $\mathrm{d}^{9}$ configuration at $516 \mathrm{~nm}$ assigned to ${ }^{2} \mathrm{~B}_{1 \mathrm{~g}} \rightarrow{ }^{2} \mathrm{~B}_{2 \mathrm{~g}}$ transition was observed in the $\mathrm{Cu}(\mathrm{Bmpp}-\mathrm{Ph})_{2}\left(\mathrm{H}_{2} \mathrm{O}\right)_{2} \cdot \mathrm{H}_{2} \mathrm{O}$ spectrum (Figure 10) and the same transition is seen as a weak, but broad, band at $594 \mathrm{~nm}$ for $\mathrm{Cu}(\mathrm{Ampp}-\mathrm{Ph})_{2}\left(\mathrm{H}_{2} \mathrm{O}\right)_{2}$ [41]. $\mathrm{Cu}(\mathrm{Bmpp}-\mathrm{Ph})_{2}\left(\mathrm{H}_{2} \mathrm{O}\right)_{2} \cdot \mathrm{H}_{2} \mathrm{O}$ had a magnetic moment of $1.94 \mathrm{BM}$ and $\mathrm{Cu}(\mathrm{Ampp}-\mathrm{Ph})_{2}\left(\mathrm{H}_{2} \mathrm{O}\right)_{2}$, a magnetic moment of $1.93 \mathrm{BM}$ which corroborates the $\mathrm{d}^{9}$ octahedral $\mathrm{Cu}(\mathrm{II})$ complex proposed [39].

\subsection{Thermogravimetric Studies}

Metal complexes of phenylhydrazones reported herein are generally thermally stable. In their thermograms, a multistep decomposition pattern is observed with the final decomposition occurring beyond $900{ }^{\circ} \mathrm{C}$, marking their corresponding weight loss assignment unfavorable. However, it is expected that final decomposition will be equivalent to the weight loss associated with residue of the corresponding metal oxides. The two coordinated water molecules common to all metal complexes are 
expected to decompose at around $140-300^{\circ} \mathrm{C}$ [42] and the uncoordinated water usually decomposes a little earlier.

Two decompositions of about $8 \%$ weight loss calculated as $4 \%$ was observed in the thermogram of $\mathrm{Mn}(\mathrm{Bmpp}-\mathrm{Dh})_{2}\left(\mathrm{H}_{2} \mathrm{O}\right)_{2}$ at $240{ }^{\circ} \mathrm{C}$, associated with the coordinated and uncoordinated water molecules, as well as other water molecules which the complex have absorbed as lattice water (Figure 11). At around $390{ }^{\circ} \mathrm{C}$, a major decomposition occurred which may be due to the removal of one of its ligands calculated as $46 \%$, and followed by another one over a wide temperature range extending above $900{ }^{\circ} \mathrm{C}$, which is as a result of the removal of the other Schiff base ligand leaving behind the $\mathrm{MnO}$ residue. A similar decomposition pattern was observed in $\mathrm{Mn}(\mathrm{Ampp}-\mathrm{Dh})_{2}\left(\mathrm{H}_{2} \mathrm{O}\right)_{2} \cdot \mathrm{H}_{2} \mathrm{O}$ (Figure 11), with a weight loss due to the coordinated and non-coordinated water molecules around $190{ }^{\circ} \mathrm{C}$ with a weight percentage loss of $7 \%$, theoretically calculated as $6 \%$. The major decomposition at around $310^{\circ} \mathrm{C}$ may be due to one Schiff base ligand calculated for $44 \%$, and the wide temperature range decomposition extending beyond $900{ }^{\circ} \mathrm{C}$, tentatively, due to the second Schiff base ligand molecule leaving behind the manganese oxide.

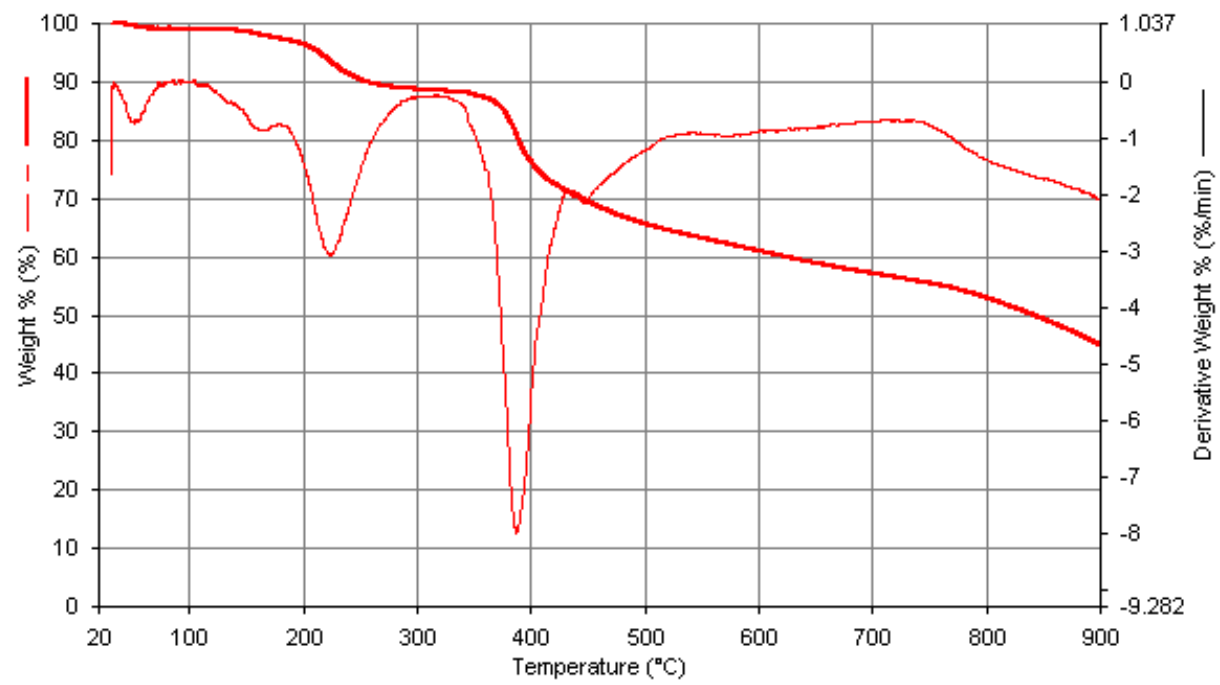

(I)

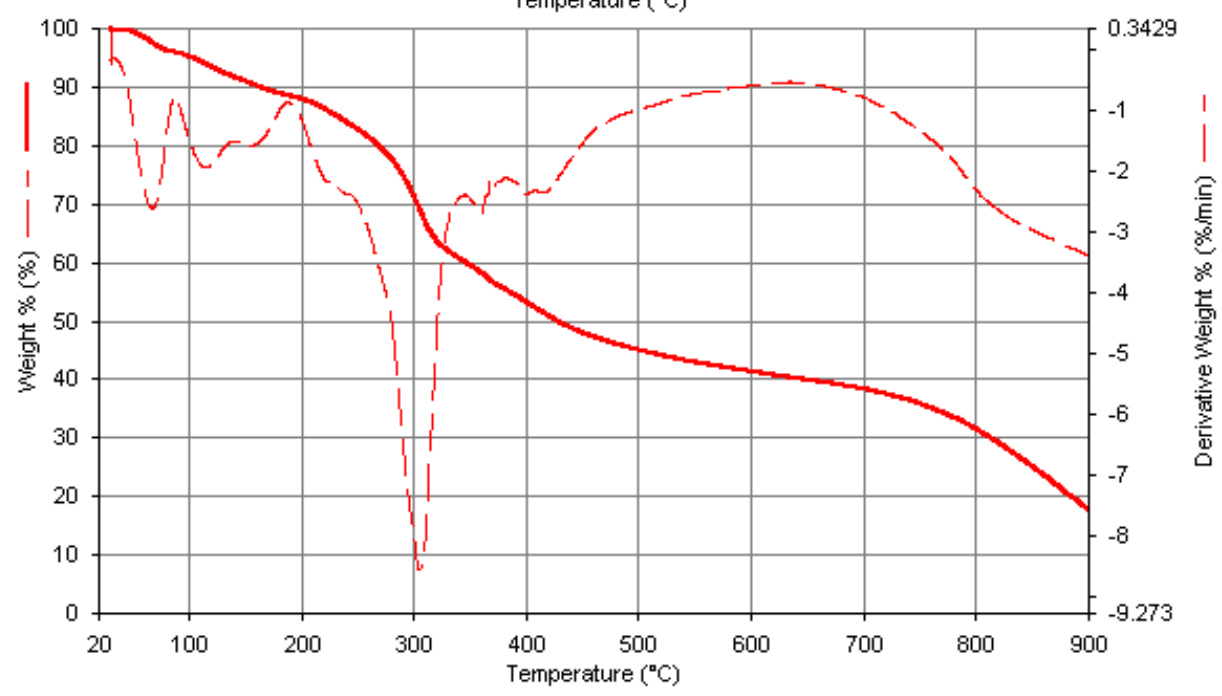

(II)

Figure 11. Thermogravimetric analysis curves of metal complexes. (I) $\mathrm{Mn}(\mathrm{Bmpp}-\mathrm{Dh})_{2}\left(\mathrm{H}_{2} \mathrm{O}\right)_{2}$; and (II) $\mathrm{Mn}(\mathrm{Ampp}-\mathrm{Dh})_{2}\left(\mathrm{H}_{2} \mathrm{O}\right)_{2} \cdot \mathrm{H}_{2} \mathrm{O}$.

In $\mathrm{Mn}(\mathrm{Bmpp}-\mathrm{Ph})_{2}\left(\mathrm{H}_{2} \mathrm{O}\right)_{2} \cdot 2 \mathrm{H}_{2} \mathrm{O}$ (Figure 12), the first few decompositions observed, totaling to about $8.0 \%$ at around $200{ }^{\circ} \mathrm{C}$, are probably due to the removal of four coordinated and uncoordinated water molecules calculated as $8.4 \%$. A major decomposition at $475{ }^{\circ} \mathrm{C}$ with a \% weight loss of 
approximately $48 \%$ may be due to the removal of one Schiff base molecule, which is theoretically calculated as $43 \%$. A final decomposition at $800^{\circ} \mathrm{C}$ with a total mass loss of approximately $93 \%$ is, tentatively, due to the removal of the water molecules and the Schiff base ligands calculated as approximately $92 \%$, leaving behind the corresponding manganese oxide with approximately $7 \%$, calculated as $8.2 \%$.
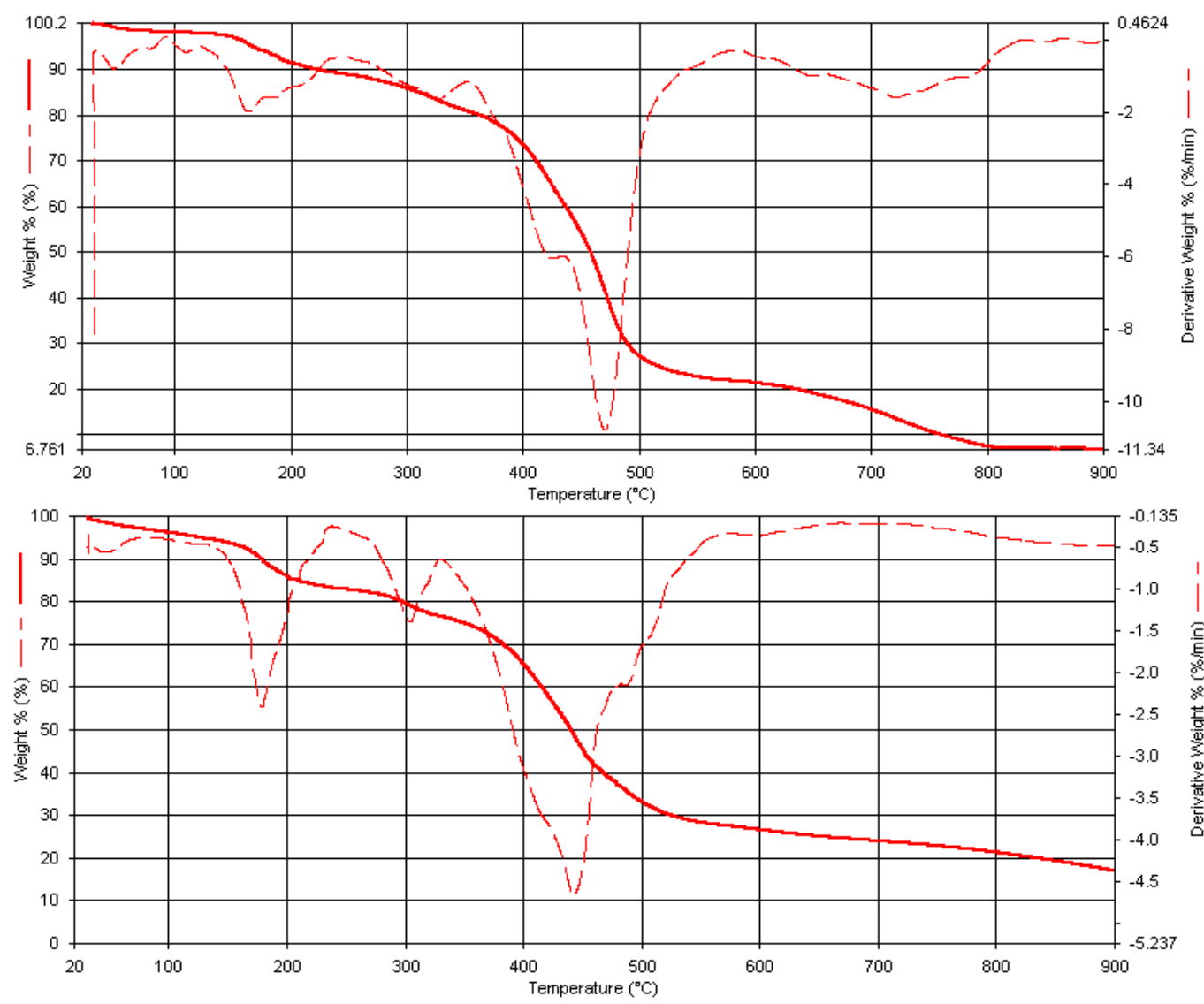

Figure 12. Thermogravimetric analysis curves of metal complexes. (I) $\mathrm{Mn}(\mathrm{Bmpp}-\mathrm{Ph})_{2}\left(\mathrm{H}_{2} \mathrm{O}\right)_{2} \cdot 2 \mathrm{H}_{2} \mathrm{O}$; and (II) $\mathrm{Co}(\mathrm{Bmpp}-\mathrm{Ph})_{2}\left(\mathrm{H}_{2} \mathrm{O}\right)_{2} \cdot \mathrm{H}_{2} \mathrm{O}$.

The removal of the water molecules can be observed in the thermogram of $\mathrm{Co}(\mathrm{Bmpp}-\mathrm{Dh})_{2}\left(\mathrm{H}_{2} \mathrm{O}\right)_{2} \cdot \mathrm{H}_{2} \mathrm{O}$, as a multiple decomposition between 0 and $240{ }^{\circ} \mathrm{C}$ with a total mass percentage loss of about $11 \%$ which is calculated as $5 \%$. The major decomposition at $360{ }^{\circ} \mathrm{C}$ may be due to one of the Schiff base ligands. Additionally, the last decomposition observed extends beyond $900{ }^{\circ} \mathrm{C}$. The absence of an uncoordinated water molecule is evident in the thermogram of $\mathrm{Co}(\mathrm{Ampp}-\mathrm{Dh})_{2}\left(\mathrm{H}_{2} \mathrm{O}\right)_{2}$. The major decomposition at $370{ }^{\circ} \mathrm{C}$ may be due to the elimination of the two coordinated water molecules. The other two decompositions observed from Thermogravimetric derivative (DTG) at around 510 and $600{ }^{\circ} \mathrm{C}$ could not be assigned. The formation of a gaseous product may be the cause of the unusual thermograms observed.

The thermal analysis of both $\mathrm{Co}(\mathrm{Bmpp}-\mathrm{Ph})_{2}\left(\mathrm{H}_{2} \mathrm{O}\right)_{2} \cdot \mathrm{H}_{2} \mathrm{O}$ and $\mathrm{Co}(\mathrm{Ampp}-\mathrm{Ph})_{2}\left(\mathrm{H}_{2} \mathrm{O}\right)_{2} \cdot 2 \mathrm{H}_{2} \mathrm{O}$, as seen in their thermograms, exhibited multistep decompositions. However, the decomposition around 170 and $300{ }^{\circ} \mathrm{C}$ corresponds to the elimination of water molecules. The final weight loss of $92.3 \%$, calculated as $91.2 \%$ at $>900{ }^{\circ} \mathrm{C}$ for $\mathrm{Co}(\mathrm{Bmpp}-\mathrm{Ph})_{2}\left(\mathrm{H}_{2} \mathrm{O}\right)_{2} \cdot \mathrm{H}_{2} \mathrm{O}$, and a final weight loss of $89.9 \%$, calculated as $90.6 \%$ at $>900{ }^{\circ} \mathrm{C}$ for $\mathrm{Co}(\mathrm{Ampp}-\mathrm{Ph})_{2}\left(\mathrm{H}_{2} \mathrm{O}\right)_{2} \cdot 2 \mathrm{H}_{2} \mathrm{O}$ (Figure 13), corresponding to the decomposition of the water molecules and ligands, respectively, were observed, leaving behind a residue of cobalt oxide with percentage mass of $10.4 \%$ (calc. $9.5 \%$ ) and $10 \%$ (calc. $10.1 \%$ ), respectively. 


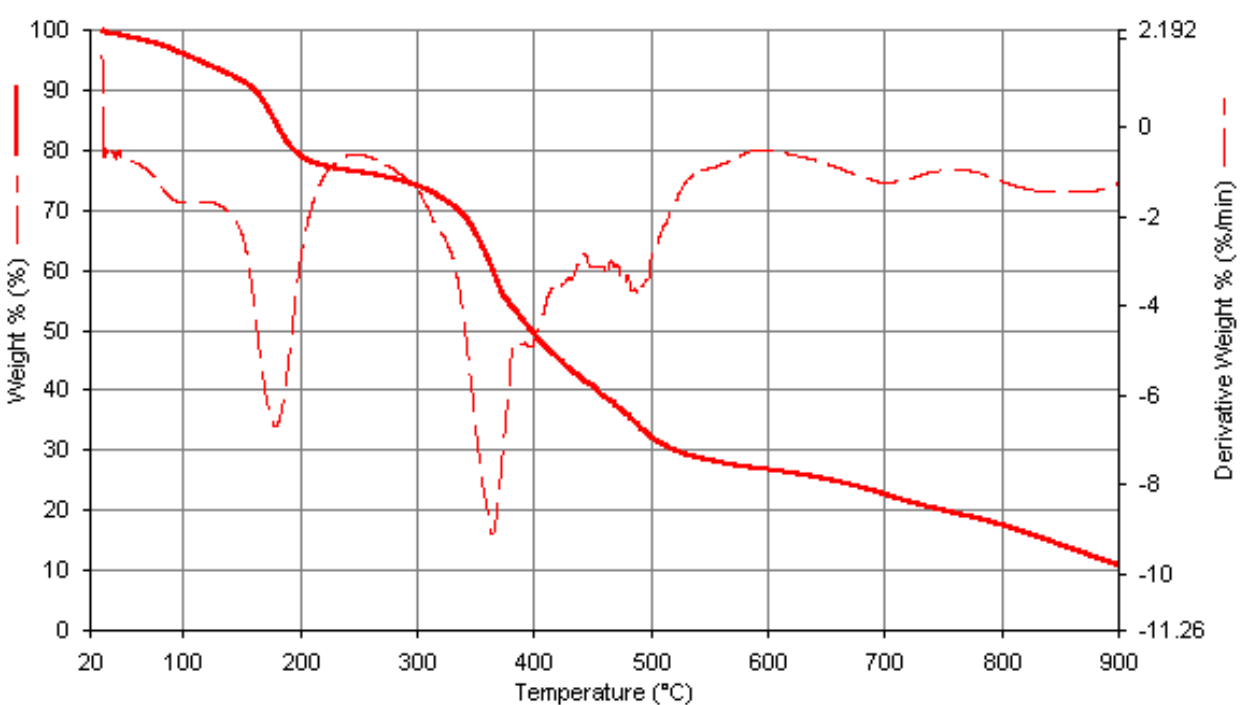

(I)

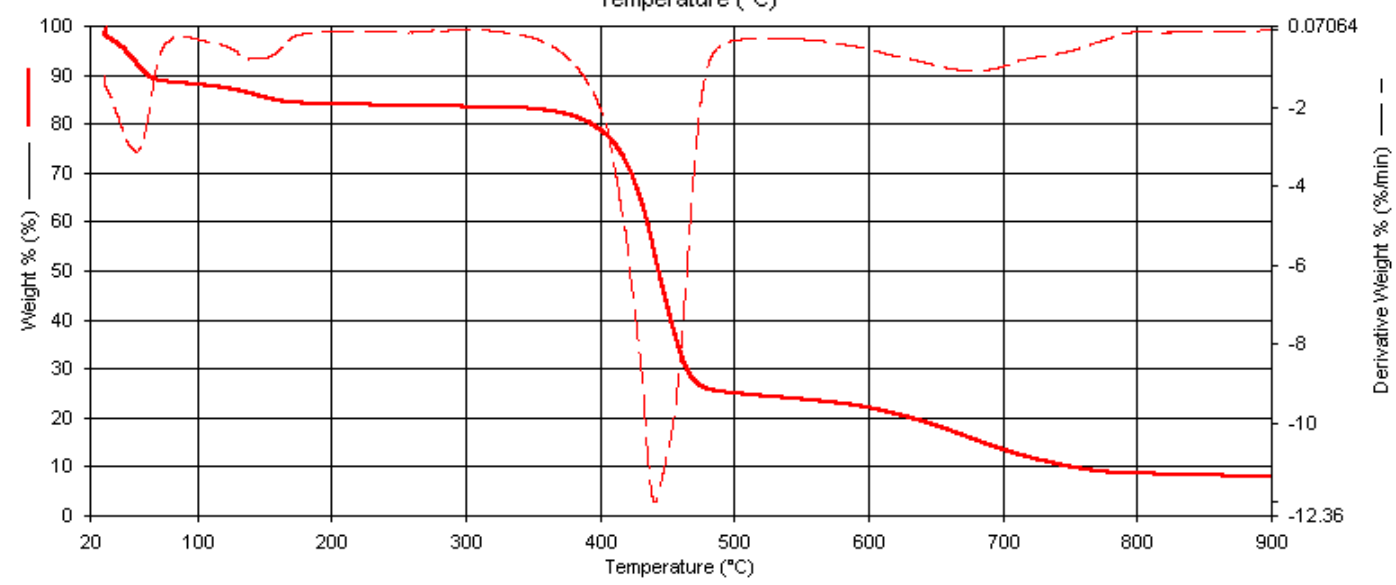

(II)

Figure 13. Thermogravimetric analysis curves of metal complexes. (I) $\mathrm{Co}(\mathrm{Ampp}-\mathrm{Ph})_{2}\left(\mathrm{H}_{2} \mathrm{O}\right)_{2} \cdot 2 \mathrm{H}_{2} \mathrm{O}$; and (II) $\mathrm{Ni}(\mathrm{Bmpp}-\mathrm{Ph})_{2}\left(\mathrm{H}_{2} \mathrm{O}\right)_{2} \cdot 2 \mathrm{H}_{2} \mathrm{O}$.

Removal of the three water molecules in $\mathrm{Ni}(\mathrm{Bmpp}-\mathrm{Dh})_{2}\left(\mathrm{H}_{2} \mathrm{O}\right)_{2} \cdot \mathrm{H}_{2} \mathrm{O}$ was evident from the multistep decomposition with $8 \%$ weight loss, theoretically calculated as $7 \%$, occurring at around $240{ }^{\circ} \mathrm{C}$. This was followed by a major decomposition at $390^{\circ} \mathrm{C}$ which may be assigned to the removal of one Schiff base ligand. The last decomposition over a wide range of temperature may be due to the second Schiff base leaving behind the residue of the metal oxide.

A similar pattern was observed in $\mathrm{Ni}(\mathrm{Ampp}-\mathrm{Dh})_{2}\left(\mathrm{H}_{2} \mathrm{O}\right)_{2}$. The water molecule removal was evident from the DTG curve of decomposition at $160{ }^{\circ} \mathrm{C}$, and the major decomposition at around $298^{\circ} \mathrm{C}$ may be attributed to the removal of the ligand, although the decomposition temperature is low. Multiple decompositions are observed in $\mathrm{Ni}(\mathrm{Ampp}-\mathrm{Dh})_{2}\left(\mathrm{H}_{2} \mathrm{O}\right)_{2}$ and, as such, the metal complex component assignments were not possible at this time.

The total weight percent loss of about $12 \%$ in two steps observed in the $\mathrm{Ni}(\mathrm{Bmpp}-\mathrm{Ph})_{2}\left(\mathrm{H}_{2} \mathrm{O}\right)_{2} \cdot 2 \mathrm{H}_{2} \mathrm{O}$ thermogram can be attributed to the loss of water molecules (Figure 13). A major decomposition is observed at around $440{ }^{\circ} \mathrm{C}$ with a mass percentage loss of $58 \%$, which may be attributed to one molecule of the ligand, calculated at approximately $43 \%$. The third decomposition at $760{ }^{\circ} \mathrm{C}$ may be the removal of the second ligand molecule, leaving behind a residue of the metal oxide with a weight percentage loss of $8 \%$ (calc. as $8.6 \%$ ) in Ni(Bmpp-Ph) $)_{2}\left(\mathrm{H}_{2} \mathrm{O}\right)_{2} \cdot 2 \mathrm{H}_{2} \mathrm{O}$.

Both copper complexes of the two 2,4-dinitrophenylhdrazones exhibited a major decomposition at $380{ }^{\circ} \mathrm{C}$, this decompositions may be due to the removal of one Schiff base ligand, followed by another decomposition over a wide temperature range which is associated with the removal of the second Schiff base. The presence of the uncoordinated water molecule is obvious in 
$\mathrm{Cu}(\mathrm{Bmpp}-\mathrm{Dh})_{2}\left(\mathrm{H}_{2} \mathrm{O}\right)_{2} \cdot 2 \mathrm{H}_{2} \mathrm{O}$ with a decomposition at around $100{ }^{\circ} \mathrm{C}$, followed by the removal of a coordinated water molecule at $200^{\circ} \mathrm{C}$. The DTG curve reveals some decomposition around $220^{\circ} \mathrm{C}$ which is due to the coordinated water molecule and absence of any decomposition earlier than this is evidence of no lattice water molecules.

Three main decompositions has been observed for $\mathrm{Cu}(\mathrm{Bmpp}-\mathrm{Ph})_{2}\left(\mathrm{H}_{2} \mathrm{O}\right)_{2} \cdot \mathrm{H}_{2} \mathrm{O}$ amongst other decompositions according to the DTG curve that could not be directly assigned (Figure 14). However, the decomposition at $290^{\circ} \mathrm{C}$ may be as a result of the removal of the two coordinating water molecules, followed by a second major mass percentage loss at $420^{\circ} \mathrm{C}$ assigned to the removal of a molecule of the Schiff base ligand. The final mass percentage loss at $785^{\circ} \mathrm{C}$ is equivalent to the removal of the water molecules and the ligands, leaving behind the copper oxide with a mass percentage of approximately $12 \%$, which is calculated as $10 \%$. One major decomposition at $370^{\circ} \mathrm{C}$ was obtained in the thermogram of $\mathrm{Cu}(\mathrm{Ampp}-\mathrm{Dh})_{2}\left(\mathrm{H}_{2} \mathrm{O}\right)_{2}$ (Figure 14), which may be assigned to the removal of the two coordinating water molecules. Although other components of the copper complex cannot be accounted for with the minimal information from its TG/DTG curves, a final decomposition at $>900^{\circ} \mathrm{C}$ gave a residue of $\mathrm{CuO}$ with a percentage mass of $11.8 \%$, calculated for $11.2 \%$.
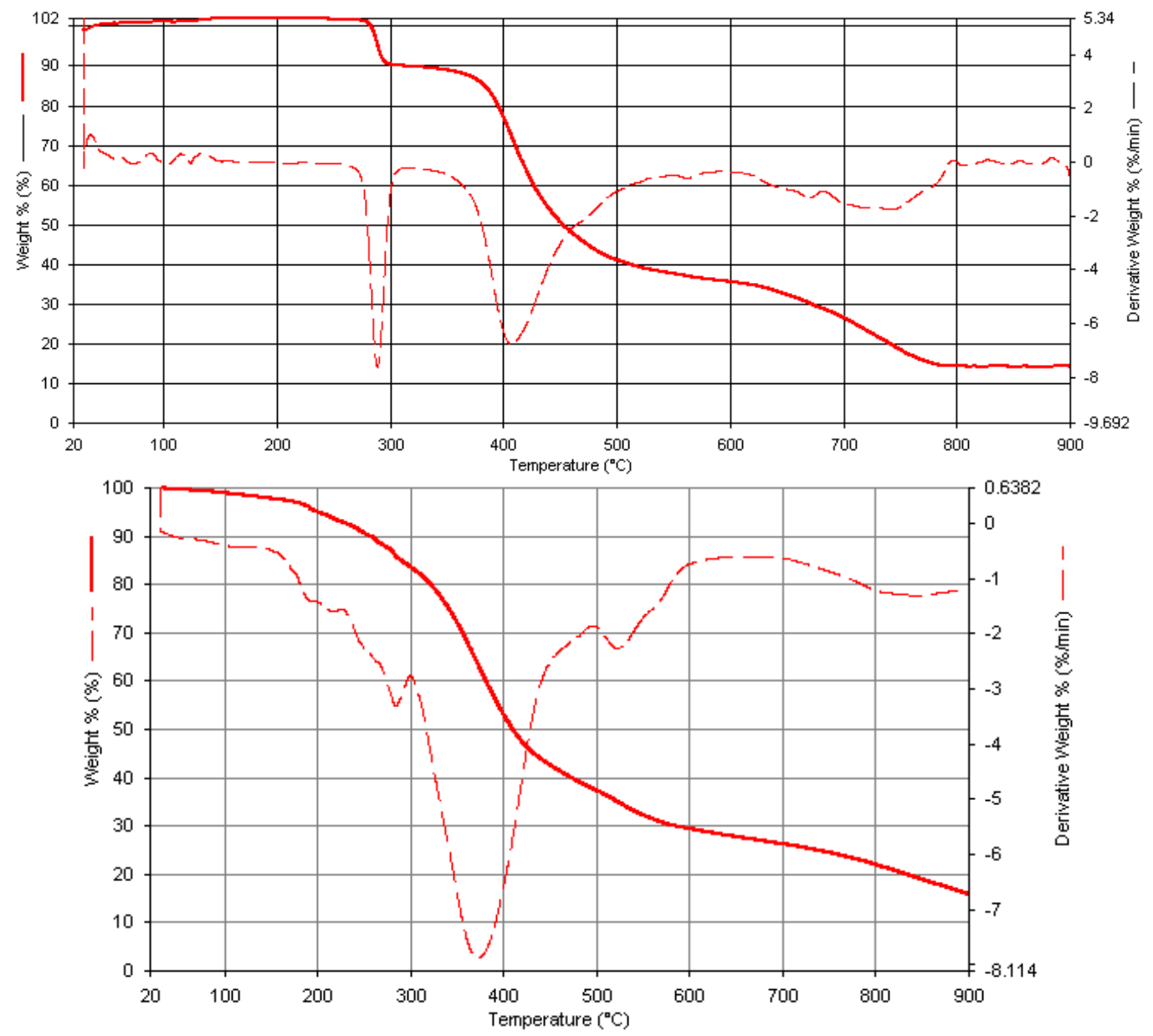

Figure 14. Thermogravimetric analysis curves of metal complexes. (I) $\mathrm{Cu}(\mathrm{Bmpp}-\mathrm{Ph})_{2}\left(\mathrm{H}_{2} \mathrm{O}\right)_{2} \cdot \mathrm{H}_{2} \mathrm{O}$; and (II) $\mathrm{Cu}(\mathrm{Ampp}-\mathrm{Ph})_{2}\left(\mathrm{H}_{2} \mathrm{O}\right)_{2}$.

Based on elemental analysis, spectroscopic and thermal studies, the proposed structural scheme for metal complexes is presented in Figure 15. 


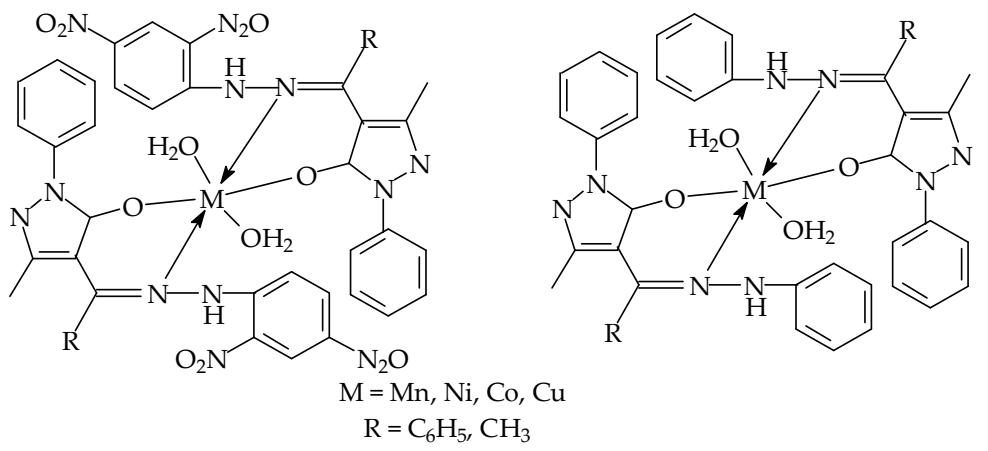

Figure 15. Proposed structure schemes of phenylhydrazone metal complexes.

\subsection{Biological Studies}

The zones of inhibition from in vitro antibacterial screening of phenylhydrazones and their metal complexes are reported, using the paper disc diffusion method, are presented in Table 2. The compounds have shown a generally low antibacterial activity compared to chloramphenicol with different inhibition zones. Ampp-Dh showed a highest zone of inhibition at $24 \mathrm{~mm}$ against Staphylococus aureus, which was followed by $\mathrm{Co}(\mathrm{Ampp}-\mathrm{Dh})_{2}\left(\mathrm{H}_{2} \mathrm{O}\right)_{2}$ with 20 and $15.5 \mathrm{~mm}$ against Gram-negative Aeromonas hydrophillia and Staphylococus aureus, respectively. $\mathrm{Ni}(\mathrm{Bmpp}-\mathrm{Dh})_{2}\left(\mathrm{H}_{2} \mathrm{O}\right)_{2} \cdot \mathrm{H}_{2} \mathrm{O}$ displayed a broad spectrum activity, having a positive inhibition against all selected bacterial isolates and may be referred to as most active compound on the list [43].

Table 2. Zone of growth inhibition exhibited by phenylhydrazone and metal complexes at $40 \mathrm{mg} / \mathrm{mL}(\mathrm{mm})$.

\begin{tabular}{|c|c|c|c|c|}
\hline Ligand and Complexes & Staphylococus aureus & Bacillus pumillus & Proteus vulgaris & Aeromonas hydrophillia \\
\hline Bmpp-Dh & 4.0 & 8.3 & NI & NI \\
\hline Ampp-Dh & 24.0 & 9.5 & NI & 4.5 \\
\hline Bmpp-Ph & 12.0 & 10.0 & 8.0 & NI \\
\hline $\mathrm{Co}(\mathrm{Bmpp}-\mathrm{Ph})_{2}\left(\mathrm{H}_{2} \mathrm{O}\right)_{2} \cdot \mathrm{H}_{2} \mathrm{O}$ & 8.0 & 12.0 & NI & NI \\
\hline $\mathrm{Ni}(\mathrm{Bmpp}-\mathrm{Ph})_{2}\left(\mathrm{H}_{2} \mathrm{O}\right)_{2} \cdot 2 \mathrm{H}_{2} \mathrm{O}$ & NI & 8.0 & 4.0 & 10.0 \\
\hline $\mathrm{Cu}(\mathrm{Bmpp}-\mathrm{Ph})_{2}\left(\mathrm{H}_{2} \mathrm{O}\right)_{2} \cdot \mathrm{H}_{2} \mathrm{O}$ & 12.0 & 6.0 & 8.0 & NI \\
\hline $\mathrm{Mn}(\mathrm{Bmpp}-\mathrm{Dh})_{2}\left(\mathrm{H}_{2} \mathrm{O}\right)_{2}$ & 8.0 & 7.0 & NI & NI \\
\hline $\mathrm{Cu}(\mathrm{Bmpp}-\mathrm{Dh})_{2}\left(\mathrm{H}_{2} \mathrm{O}\right)_{2} \cdot 2 \mathrm{H}_{2} \mathrm{O}$ & NI & 8.5 & NI & 12.0 \\
\hline $\mathrm{Co}(\mathrm{Ampp}-\mathrm{Ph})_{2}\left(\mathrm{H}_{2} \mathrm{O}\right)_{2} \cdot 2 \mathrm{H}_{2} \mathrm{O}$ & 8.0 & 12.0 & NI & 6.0 \\
\hline $\mathrm{Cu}(\mathrm{Ampp}-\mathrm{Ph})_{2}\left(\mathrm{H}_{2} \mathrm{O}\right)_{2}$ & 4.0 & 4.0 & NI & NI \\
\hline $\mathrm{Mn}(\text { Ampp-Dh })_{2}\left(\mathrm{H}_{2} \mathrm{O}\right)_{2} \cdot \mathrm{H}_{2} \mathrm{O}$ & 8.0 & 8.5 & 9.5 & 5.0 \\
\hline $\mathrm{Co}(\mathrm{Ampp}-\mathrm{Dh})_{2}\left(\mathrm{H}_{2} \mathrm{O}\right)_{2}$ & 15.5 & 4.0 & NI & 20.0 \\
\hline $\mathrm{Ni}(\mathrm{Ampp}-\mathrm{Dh})_{2}\left(\mathrm{H}_{2} \mathrm{O}\right)_{2}$ & 8.0 & 12.5 & NI & 8.3 \\
\hline $\mathrm{Cu}(\mathrm{Ampp}-\mathrm{Dh})_{2}\left(\mathrm{H}_{2} \mathrm{O}\right)_{2}$ & 13.0 & 12.3 & NI & 20 \\
\hline
\end{tabular}

$\mathrm{NI}=$ no inhibition

The antioxidant (free radical scavenging) activity of synthesized compounds under investigation, against DPPH, were of interesting characteristics, although at $0.50 \mathrm{mg} / \mathrm{mL}$ the two 2,4-dinitrophenylhydrazones, $\mathrm{Mn}(\mathrm{Bmpp}-\mathrm{Dh})_{2}\left(\mathrm{H}_{2} \mathrm{O}\right)_{2}, \quad \mathrm{Co}(\mathrm{Ampp}-\mathrm{Dh})_{2}\left(\mathrm{H}_{2} \mathrm{O}\right)_{2}$, and $\mathrm{Cu}(\mathrm{Bmpp}-\mathrm{Ph})_{2}\left(\mathrm{H}_{2} \mathrm{O}\right)_{2} \cdot \mathrm{H}_{2} \mathrm{O}$ did not show any activity. $\mathrm{Cu}(\mathrm{Bmpp}-\mathrm{Dh})_{2}\left(\mathrm{H}_{2} \mathrm{O}\right)_{2} \cdot 2 \mathrm{H}_{2} \mathrm{O}$ had the strongest antioxidant activity with a highest percentage scavenging activity value of $89.90 \%$ at $0.25 \mathrm{mg} / \mathrm{mL}$, close to that of the standard drug, ascorbic acid (Table 3). This was in agreement with reported work on synthesized compounds with metal ion coordination [44].

The metal complexes with Bmpp-Dh exhibited a generally-increased activity than their ligand. Specifically, $\mathrm{Ni}(\mathrm{Bmpp}-\mathrm{Dh})_{2}\left(\mathrm{H}_{2} \mathrm{O}\right)_{2} \cdot \mathrm{H}_{2} \mathrm{O}$ and $\mathrm{Cu}(\mathrm{Bmpp}-\mathrm{Dh})_{2}\left(\mathrm{H}_{2} \mathrm{O}\right)_{2} \cdot 2 \mathrm{H}_{2} \mathrm{O}$ showed a significant increase in antioxidant property at 0.5 and $0.25 \mathrm{mg} / \mathrm{mL}$, respectively, compared to their free Schiff base ligand (Figure 16). 
Table 3. Antioxidant scavenging activity data of 2,4-dinitrophenylhydrazones and their metal complexes (\%).

\begin{tabular}{|c|c|c|c|}
\hline \multirow{2}{*}{ Ligand and Complexes } & \multicolumn{3}{|c|}{ Percentage Antioxidant Activity } \\
\hline & $0.50 \mathrm{mg} / \mathrm{mL}$ & $0.25 \mathrm{mg} / \mathrm{mL}$ & $0.13 \mathrm{mg} / \mathrm{mL}$ \\
\hline Bmpp-Dh 1 & - & 31.05 & 30.70 \\
\hline Ampp-Dh 2 & - & 63.27 & 76.33 \\
\hline Bmpp-Ph 3 & 62.48 & 89.11 & 87.79 \\
\hline $\mathrm{Mn}(\mathrm{Bmpp}-\mathrm{Ph})_{2}\left(\mathrm{H}_{2} \mathrm{O}\right)_{2} \cdot 2 \mathrm{H}_{2} \mathrm{O} 3 \mathrm{a}$ & 52.42 & 42.76 & 64.61 \\
\hline $\mathrm{Co}(\mathrm{Bmpp}-\mathrm{Ph})_{2}\left(\mathrm{H}_{2} \mathrm{O}\right)_{2} \cdot \mathrm{H}_{2} \mathrm{O} 3 \mathrm{~b}$ & 17.22 & 3.13 & 32.32 \\
\hline $\mathrm{Ni}(\mathrm{Bmpp}-\mathrm{Ph})_{2}\left(\mathrm{H}_{2} \mathrm{O}\right)_{2} \cdot 2 \mathrm{H}_{2} \mathrm{O} 3 \mathrm{c}$ & 37.33 & 4.17 & 40.94 \\
\hline $\mathrm{Cu}(\mathrm{Bmpp}-\mathrm{Ph})_{2}\left(\mathrm{H}_{2} \mathrm{O}\right)_{2} \cdot \mathrm{H}_{2} \mathrm{O} 3 \mathrm{~d}$ & - & 12.98 & 1.73 \\
\hline $\mathrm{Mn}(\mathrm{Bmpp}-\mathrm{Dh})_{2}\left(\mathrm{H}_{2} \mathrm{O}\right)_{2} 1 \mathrm{a}$ & - & 68.83 & 52.28 \\
\hline $\mathrm{Co}(\mathrm{Bmpp}-\mathrm{Dh})_{2}\left(\mathrm{H}_{2} \mathrm{O}\right)_{2} \cdot \mathrm{H}_{2} \mathrm{O} 1 \mathrm{~b}$ & 8.58 & 59.56 & 47.11 \\
\hline $\mathrm{Ni}(\mathrm{Bmpp}-\mathrm{Dh})_{2}\left(\mathrm{H}_{2} \mathrm{O}\right)_{2} \cdot \mathrm{H}_{2} \mathrm{O} 1 \mathrm{c}$ & 87.92 & 62.80 & 61.28 \\
\hline $\begin{array}{c}\mathrm{Cu}(\mathrm{Bmpp}-\mathrm{Dh})_{2}\left(\mathrm{H}_{2} \mathrm{O}\right)_{2} \cdot 2 \mathrm{H}_{2} \mathrm{O} \\
1 \mathrm{~d}\end{array}$ & 2.28 & 89.90 & 53.76 \\
\hline $\mathrm{Co}(\mathrm{Ampp}-\mathrm{Ph})_{2}\left(\mathrm{H}_{2} \mathrm{O}\right)_{2} \cdot 2 \mathrm{H}_{2} \mathrm{O} 4 \mathrm{a}$ & 60.07 & 87.25 & 80.64 \\
\hline $\mathrm{Cu}(\mathrm{Ampp}-\mathrm{Ph})_{2}\left(\mathrm{H}_{2} \mathrm{O}\right)_{2} 4 \mathrm{~b}$ & 38.35 & 57.36 & 44.76 \\
\hline $\mathrm{Mn}(\mathrm{Ampp}-\mathrm{Dh})_{2}\left(\mathrm{H}_{2} \mathrm{O}\right)_{2} \cdot \mathrm{H}_{2} \mathrm{O} 2 \mathrm{a}$ & 68.48 & 85.86 & 87.42 \\
\hline $\mathrm{Co}(\mathrm{Ampp}-\mathrm{Dh})_{2}\left(\mathrm{H}_{2} \mathrm{O}\right)_{2} 2 \mathrm{~b}$ & - & 55.50 & 55.98 \\
\hline $\mathrm{Ni}(\mathrm{Ampp}-\mathrm{Dh})_{2}\left(\mathrm{H}_{2} \mathrm{O}\right)_{2} 2 \mathrm{c}$ & 65.32 & 84.01 & 84.83 \\
\hline $\mathrm{Cu}(\mathrm{Ampp}-\mathrm{Dh})_{2}\left(\mathrm{H}_{2} \mathrm{O}\right)_{2} 2 \mathrm{~d}$ & 35.73 & 85.40 & 82.98 \\
\hline Ascorbic acid std & 87.62 & 93.63 & 91.99 \\
\hline
\end{tabular}

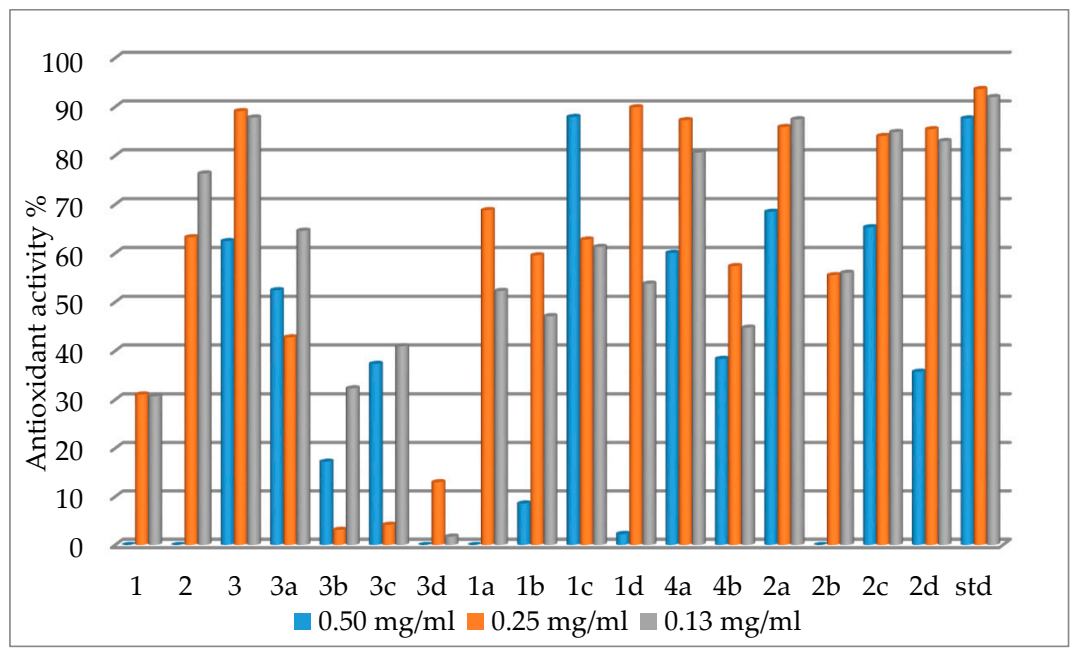

Figure 16. Chart showing the antioxidant activities of phenylhydrazones and their metal complexes.

Additionally, in Figure 16, a generally higher antioxidant activity for metal complexes have been observed with those of acetylpyrazolone-based 2,4-dinitrophenylhydrazone and this was peculiar in all different concentrations. $\mathrm{Mn}(\mathrm{Ampp}-\mathrm{Dh})_{2}\left(\mathrm{H}_{2} \mathrm{O}\right)_{2} \cdot \mathrm{H}_{2} \mathrm{O}$ exhibited the strongest activity across all concentration values.

\section{Materials and Methods}

\subsection{Materials and Physical Measurements}

Commercially available analytical reagents, transition metal salts, dinitrophenylhydrazine, phenylhydrazine, 3-methyl-1-phenyl-2-pyrazolin-5-one, and solvents were used as supplied. The melting point of synthesized compounds that gives, somewhat, of an idea of the molecules' purity was performed using the GallenKamp melting point apparatus (Northampton, UK). Elemental analyses to determine the compositions in percentage of CHN were carried out on a LECO.TRUSpec Micro CHNS analyzer (St. Joseph, MI, USA). FTIR spectra were measured on a Perkin-Elmer Model System 2000 FTIR spectrometer (Shelton, CT, USA) using KBr pellets $\left(370-4000 \mathrm{~cm}^{-1}\right)$. The electronic spectra of metal complexes were made possible using a Perkin-Elmer Lambda 25 spectrometer (Waltham, MA, USA). A Sherwood Scientific magnetic susceptibility balance was used for magnetic moments 
of the complexes at room temperature and diamagnetism corrections were estimated from Pascal's constants. ${ }^{1} \mathrm{H}$ and ${ }^{13} \mathrm{C}$ NMR spectra were recorded in deuterated DMSO on a Bruker $600 \mathrm{MHz}$ Avance II NMR spectrophotometer (Lyon, Rhône-Alpes, France) using trimethylsilane TMS, as the internal standard. Thermal analyses were done on a NETZSCH STA 449 C instrument (Selb, Bavaria, Germany) at a temperature range of $20-900{ }^{\circ} \mathrm{C}$ with a heating rate of $20^{\circ} \mathrm{C} \cdot \mathrm{min}^{-1}$ in nitrogen gas. The Bruker micrOTOF-Q II 10390 mass spectrometer (Billerica, MA, USA) was employed to measure the mass spectra of ligands, which was analyzed with ACPI using a direct insertion probe (DIP). An external calibration with sodium formate was performed to attain the correct accurate mass. Single crystal X-ray diffraction studies were performed on a Bruker Kappa Apex II diffractometer (Madison, WI, USA) with graphite-monochromated Mo K $\alpha$ radiation $(\lambda=0.71073 \AA)$. Acylpyrazolone Schiff base precursors 4-acetyl-3-methyl-1-phenyl-2-pyrazolin-5-one and 4-benzoyl-3-methyl-1-phenyl-2-pyrazolin-5-one were synthesized as previously reported [45].

\subsection{Synthesis of Phenylhydrazones}

A solution of 4-acetyl-3-methyl-1-phenyl-2-pyrazolin-5-one $(2.0 \mathrm{mmol}, 0.43 \mathrm{~g})$ and 4-benzoyl-3-methyl-1-phenyl-2-pyrazolin-5-one ( $2.0 \mathrm{mmol}, 0.56 \mathrm{~g})$ in methanol $(40 \mathrm{~mL})$, each in a separate round-bottom flask, was reacted with phenylhydrazine $(2.0 \mathrm{mmol}, 0.22 \mathrm{~g})$ in methanol $(10 \mathrm{~mL})$ and 2,4-dinitrophenylhydrazine $(2.0 \mathrm{mmol}, 0.40 \mathrm{~g})$ in hot methanol $(40 \mathrm{~mL})$ under reflux for $4 \mathrm{~h}$ to precipitate red 4-acetyl-3-methyl-1-phenyl-2-pyrazolin-5-one dinitrophenylhydrazone (Ampp-Dh), red 4-benzoyl-3-methyl-1-phenyl-2-pyrazolin-5-one dinitrophenylhydrazone (Bmpp-Dh) and yellow 4-beenzoyl-3-methyl-1-phenyl-2-pyrazolin-5-one phenylhydrazone (Bmpp-Ph). The resulting solids in each case were filtered, washed with methanol, and dried at room temperature. They were recrystallized from methanol and stored over fused $\mathrm{CaCl}_{2}$. Gold color Ampp-Ph was synthesized in a similar way as reported earlier [25], and its golden brown block like single crystals suitable for X-ray crystallography were grown from slow evaporation of its DMF solution.

\subsubsection{4-Acetyl-3-methyl-1-phenyl-2-pyrazolin-5-one dinitrophenylhydrazone Ampp-Dh}

Yield: $74 \%$. M.p.: $217-218{ }^{\circ} \mathrm{C} .{ }^{1} \mathrm{H}$ NMR $(600 \mathrm{MHz}, \mathrm{DMSO}): \delta(\mathrm{ppm})=10.8(\mathrm{br}, 1 \mathrm{H}$, phenylhydrazine $-\mathrm{NH}), 8.8(\mathrm{~s}, 1 \mathrm{H}, \mathrm{C}=\mathrm{N}-\mathrm{H}), 8.4-7.2(\mathrm{~m}, 8 \mathrm{H}$, aromatic- $\mathrm{H}), 2.30\left(\mathrm{~s}, 3 \mathrm{H}, \mathrm{CH}_{3}\right) .{ }^{13} \mathrm{C}$ NMR $(600 \mathrm{MHz}, \mathrm{DMSO}): \delta(\mathrm{ppm})=146.2(\mathrm{~s}, \mathrm{C}=\mathrm{O}), 137.7(\mathrm{~s}, \mathrm{C}=\mathrm{N}), 137.9-116.0(\mathrm{~s}$, aromatic carbons), $16.2\left(\mathrm{~s}\right.$, pyrazolone $\left.\mathrm{CH}_{3}\right), 14.9$ (s, acetyl $\left.\mathrm{CH}_{3}\right)$. IR $\left(\mathrm{KBr}, \mathrm{cm}^{-1}\right)$ : $3486 v(\mathrm{~N}-\mathrm{H}), 2913 \vee(\mathrm{C}-\mathrm{H}), 1627 \vee(\mathrm{C}=\mathrm{N})$, $1501 v(\mathrm{C}=\mathrm{O})$. APCI-MS: $m / z 397.12\left([\mathrm{M}+\mathrm{H}]^{+}, 100 \%\right)$. Anal. Calcd. $\mathrm{C}_{18} \mathrm{H}_{16} \mathrm{~N}_{6} \mathrm{O}_{5}(396.12 \mathrm{~g} / \mathrm{mol}): \mathrm{C}$, $54.53 \% ; \mathrm{H}, 4.07 \%$; N, 21.21\%. Found: C, 54.20\%; H, 4.11\%; N, 20.98\%.

\subsubsection{4-Benzoyl-3-methyl-1-phenyl-2-pyrazolin-5-one dinitrophenylhydrazone Bmpp-Dp}

Yield: 73\%. M.p.: $240-242{ }^{\circ} \mathrm{C} .{ }^{1} \mathrm{H}$ NMR $(600 \mathrm{MHz}, \mathrm{DMSO}): \delta(\mathrm{ppm})=11.6(\mathrm{~s}, 1 \mathrm{H}$, phenylhydrazine -NH), $8.9(\mathrm{~s}, 1 \mathrm{H}, \mathrm{C}=\mathrm{N}-\mathrm{H}), 8.5-7.3\left(\mathrm{~m}, 13 \mathrm{H}\right.$, aromatic-H), $1.9\left(\mathrm{~s}, 3 \mathrm{H}, \mathrm{CH}_{3}\right) .{ }^{13} \mathrm{C}$ NMR $(600 \mathrm{MHz}, \mathrm{DMSO})$ : $\delta(\mathrm{ppm})=148.9(\mathrm{~s}, \mathrm{C}=\mathrm{O}), 147.4(\mathrm{~s}, \mathrm{C}=\mathrm{N}), 144.6-117.2\left(\mathrm{~m}\right.$, aromatic carbons), $13.6\left(\mathrm{~s}\right.$, pyrazolone $\left.\mathrm{CH}_{3}\right) . \mathrm{IR}$ $\left(\mathrm{KBr}, \mathrm{cm}^{-1}\right): 3489 v(\mathrm{~N}-\mathrm{H}), 2954 v(\mathrm{C}-\mathrm{H}), 1642 v(\mathrm{C}=\mathrm{N}), 1501 v(\mathrm{C}=\mathrm{O})$. APCI-MS: $\mathrm{m} / z 459.14\left([\mathrm{M}+\mathrm{H}]^{+}\right.$, $100 \%$ ). Anal. Calcd. $\mathrm{C}_{23} \mathrm{H}_{18} \mathrm{~N}_{6} \mathrm{O}_{5}(458.13 \mathrm{~g} / \mathrm{mol}): \mathrm{C}, 60.24 \%$; H, 3.96\%; N, $18.34 \%$. Found: $\mathrm{C}, 60.18 \%$; $\mathrm{H}, 3.58 \%$; N, $18.40 \%$.

\subsubsection{4-Benzoyl-3-methyl-1-phenyl-2-pyrazolin-5-one phenylhydrazone Bmpp-Ph}

Yield: 71\%. M.p.: $197-199{ }^{\circ} \mathrm{C} .{ }^{1} \mathrm{H}$ NMR $(600 \mathrm{MHz}, \mathrm{DMSO}): \delta(\mathrm{ppm})=12.2(\mathrm{br}, 1 \mathrm{H}$, phenylhydrazine -NH), $9.5(\mathrm{br}, 1 \mathrm{H}, \mathrm{C}=\mathrm{N}-\mathrm{H}), 8.4-6.8\left(\mathrm{~m}, 15 \mathrm{H}\right.$, aromatic-H), $1.9\left(\mathrm{~s}, 3 \mathrm{H}, \mathrm{CH}_{3}\right) .{ }^{13} \mathrm{C} \mathrm{NMR}$ $(600 \mathrm{MHz}, \mathrm{DMSO}): \delta(\mathrm{ppm})=168.0(\mathrm{~s}, \mathrm{C}=\mathrm{O}), 165.5(\mathrm{~s}, \mathrm{C}=\mathrm{N}), 148-115.3(\mathrm{~m}$, aromatic carbons $), 15.8$ (s, pyrazolone $\left.\mathrm{CH}_{3}\right)$. IR $\left(\mathrm{KBr}, \mathrm{cm}^{-1}\right)$ : $3491 v(\mathrm{~N}-\mathrm{H}), 2919 v(\mathrm{C}-\mathrm{H}), 1634 v(\mathrm{C}=\mathrm{N}), 1501 v(\mathrm{C}=\mathrm{O})$. Elemental analysis for $\mathrm{C}_{23} \mathrm{H}_{20} \mathrm{~N}_{4} \mathrm{O}$ (\%): found C 74.61, H 5.65, N 15.14; calculated C 74.97, H 5.47, N 15.21. Mol. mass (g/mol): 368.16. APCI-MS: $m / z 369.17\left([\mathrm{M}+\mathrm{H}]^{+}, 100 \%\right)$. 


\subsection{Synthesis of Phenylhydrazones Metal Complexes}

A solutions of Ampp-Dh (2 mmol, $0.79 \mathrm{~g})$, Bmpp-Dh (2 mmol, $0.92 \mathrm{~g})$, Ampp-Ph (2.0 mmol, $0.43 \mathrm{~g})$, and Bmpp-Ph ( $2 \mathrm{mmol}, 0.74 \mathrm{~g})$ in hot ethanol $(40 \mathrm{~mL})$, each in a separate round-bottom flask, were reacted with $1 \mathrm{mmol}$ of aqueous solution of corresponding metal salts while stirring under reflux and followed with the addition of $\mathrm{NaOH}(2 \mathrm{mmol}, 0.08 \mathrm{~g})$, to precipitate the metal complexes after $4 \mathrm{~h}$ of reflux. The resulting solutions were filtered, and their precipitates washed with ethanol/water (1:1), dried at room temperature, and stored over fused $\mathrm{CaCl}_{2}$.

3.3.1. Bis(4-acetyl-3-methyl-1-phenyl-2-pyrazolin-5-one dinitrophenylhydrazone) Diaquamanganesse (Ii) Monohydrate $\mathrm{Mn}(\mathrm{Ampp}-\mathrm{Dh})_{2}\left(\mathrm{H}_{2} \mathrm{O}\right)_{2} \cdot \mathrm{H}_{2} \mathrm{O}$

Yield: $70 \%$. M.p.: $209-211{ }^{\circ} \mathrm{C}$. Molar cond. $\left(10^{-3} \mathrm{M}\right.$ in DMF): $8.09 \mathrm{ohm}^{-1} \mathrm{~cm}^{2} \mathrm{~mol}^{-1}$. $\mu_{\text {eff }}$ (B.M.): 5.67. UV-VIS (DMF) $\lambda_{\max } \mathrm{nm}: 270\left(\pi \rightarrow \pi^{*}\right), 324,\left(\mathrm{n} \rightarrow \pi^{*}\right), 451(\mathrm{~d} \rightarrow \mathrm{d}) . \quad \mathrm{IR}\left(\mathrm{KBr}, \mathrm{cm}^{-1}\right)$ : $3489 v(\mathrm{~N}-\mathrm{H}), 3395 v(\mathrm{O}-\mathrm{H}), 2925 v(\mathrm{C}-\mathrm{H}), 1620 v(\mathrm{C}=\mathrm{N}), 840 v\left(\mathrm{H}_{2} \mathrm{O}\right), 621 v(\mathrm{M}-\mathrm{N}), 485 v(\mathrm{M}-\mathrm{O})$. Anal. Calcd. $\mathrm{C}_{36} \mathrm{H}_{36} \mathrm{~N}_{12} \mathrm{O}_{13} \mathrm{Mn}(899.19 \mathrm{~g} / \mathrm{mol}): \mathrm{C} 48.04 \%, \mathrm{H} 4.03 \%$, N 18.69\%, Found: C 48.57\%, H 5.42\%, N $18.10 \%$.

3.3.2. Bis(4-acetyl-3-methyl-1-phenyl-2-pyrazolin-5-one dinitrophenylhydrazone) Diaquacobalt(Ii) $\mathrm{Co}(\mathrm{Ampp}-\mathrm{Dh})_{2}\left(\mathrm{H}_{2} \mathrm{O}\right)_{2}$

Yield: $71 \%$. M.p.: $199-201{ }^{\circ} \mathrm{C}$. Molar cond. $\left(10^{-3} \mathrm{M}\right.$ in DMF): $11.80 \mathrm{ohm}^{-1} \mathrm{~cm}^{2} \mathrm{~mol}^{-1} \cdot \mu_{\text {eff }}($ B.M.): 4.47. UV-VIS (DMF) $\lambda_{\max } \mathrm{nm}: 268\left(\pi \rightarrow \pi^{*}\right), 324\left(\mathrm{n} \rightarrow \pi^{*}\right), 414,493(\mathrm{~d} \rightarrow \mathrm{d}) . \quad \mathrm{IR}\left(\mathrm{KBr}, \mathrm{cm}^{-1}\right): 3493$ $v(\mathrm{~N}-\mathrm{H}), 3384 v(\mathrm{O}-\mathrm{H}), 2929 v(\mathrm{C}-\mathrm{H}), 1618 v(\mathrm{C}=\mathrm{N}), 843 v\left(\mathrm{H}_{2} \mathrm{O}\right), 630 v(\mathrm{M}-\mathrm{N}), 484 v(\mathrm{M}-\mathrm{O})$. Anal. Calcd. $\mathrm{C}_{36} \mathrm{H}_{34} \mathrm{~N}_{12} \mathrm{O}_{12} \mathrm{Co}(885.17 \mathrm{~g} / \mathrm{mol}): \mathrm{C} 48.80 \%$, H 3.87\%, N 18.98\%, Found: C 48.61\%, H 3.63\%, N 18.79\%.

3.3.3. Bis(4-acetyl-3-methyl-1-phenyl-2-pyrazolin-5-one dinitrophenylhydrazone)

Diaquanickel(Ii) $\mathrm{Ni}(\text { Ampp-Dh) })_{2}\left(\mathrm{H}_{2} \mathrm{O}\right)_{2}$

Yield: $69 \%$. M.p.: $154-156{ }^{\circ} \mathrm{C}$. Molar cond. $\left(10^{-3} \mathrm{M}\right.$ in DMF): $4.40 \mathrm{ohm}^{-1} \mathrm{~cm}^{2} \mathrm{~mol}^{-1}$. $\mu_{\text {eff }}\left(\right.$ B.M.): 2.92. UV-VIS (DMF) $\lambda_{\max } \mathrm{nm:} 278\left(\pi \rightarrow \pi^{*}\right), 324\left(\mathrm{n} \rightarrow \pi^{*}\right), 436,(\mathrm{~d} \rightarrow \mathrm{d}) . \quad \mathrm{IR}\left(\mathrm{KBr}, \mathrm{cm}^{-1}\right)$ : $3495 v(\mathrm{~N}-\mathrm{H}), 3388 v(\mathrm{O}-\mathrm{H}), 2921 v(\mathrm{C}-\mathrm{H}), 1617 v(\mathrm{C}=\mathrm{N}), 849 v\left(\mathrm{H}_{2} \mathrm{O}\right), 633 v(\mathrm{M}-\mathrm{N}), 486 v(\mathrm{M}-\mathrm{O})$. Anal. Calcd. $\mathrm{C}_{36} \mathrm{H}_{40} \mathrm{~N}_{8} \mathrm{O}_{9} \mathrm{~S}_{2} \mathrm{Ni}(884.93 \mathrm{~g} / \mathrm{mol}): \mathrm{C} 48.82 \%, \mathrm{H} 3.87 \%$, N $18.99 \%$, Found: C 48.70\%, H 3.85\%, N $18.74 \%$.

3.3.4. Bis(4-acetyl-3-methyl-1-phenyl-2-pyrazolin-5-one dinitrophenylhydrazone)

Diaquacopper(Ii) $\mathrm{Cu}(\mathrm{Ampp}-\mathrm{Dh})_{2}\left(\mathrm{H}_{2} \mathrm{O}\right)_{2}$

Yield: $78 \%$. M.p.: $222-223{ }^{\circ} \mathrm{C}$. Molar cond. (10-3 M in DMF): $11.80 \mathrm{ohm}^{-1} \mathrm{~cm}^{2} \mathrm{~mol}^{-1}$. $\mu_{\text {eff }}$ (B.M.): 1.97. UV-VIS (DMF) $\lambda_{\max } \mathrm{nm}: 251\left(\pi \rightarrow \pi^{*}\right), 342\left(\mathrm{n} \rightarrow \pi^{*}\right), 467,598,(\mathrm{~d} \rightarrow \mathrm{d}) . \quad$ IR $\left(\mathrm{KBr}, \mathrm{cm}^{-1}\right): 3498$ $v(\mathrm{~N}-\mathrm{H}), 3390 v(\mathrm{O}-\mathrm{H}), 2935 v(\mathrm{C}-\mathrm{H}), 1619 v(\mathrm{C}=\mathrm{N}), 833 v\left(\mathrm{H}_{2} \mathrm{O}\right), 620 v(\mathrm{M}-\mathrm{N}), 492 v(\mathrm{M}-\mathrm{O})$. Anal. Calcd. $\mathrm{C}_{36} \mathrm{H}_{34} \mathrm{~N}_{12} \mathrm{O}_{12} \mathrm{Cu}(889.79 \mathrm{~g} / \mathrm{mol}):$ C 48.55\%, H 3.85\%, N 18.89\%, Found: C 48.49\%, H 3.96\%, N 18.54\%.

3.3.5. Bis(4-benzoyl-3-methyl-1-phenyl-2-pyrazolin-5-one dinitrophenylhydrazone) Diaquamanganese (II) $\mathrm{Mn}(\mathrm{Bmpp}-\mathrm{Dh})_{2}\left(\mathrm{H}_{2} \mathrm{O}\right)_{2}$

Yield: $76 \%$. M.p.: $240-241^{\circ} \mathrm{C}$. Molar cond. $\left(10^{-3} \mathrm{M}\right.$ in DMF): $11.40 \mathrm{ohm}^{-1} \mathrm{~cm}^{2} \mathrm{~mol}^{-1} \cdot \mu_{\text {eff }}$ (B.M.): 5.65. UV-VIS (DMF) $\lambda_{\max } \mathrm{nm}: 280\left(\pi \rightarrow \pi^{*}\right), 324\left(\mathrm{n} \rightarrow \pi^{*}\right), 436,462,(\mathrm{~d} \rightarrow \mathrm{d}) . \quad \mathrm{IR}\left(\mathrm{KBr}, \mathrm{cm}^{-1}\right): 3496$ $v(\mathrm{~N}-\mathrm{H}), 3392 v(\mathrm{O}-\mathrm{H}), 2923 v(\mathrm{C}-\mathrm{H}), 1619 v(\mathrm{C}=\mathrm{N}), 833 v\left(\mathrm{H}_{2} \mathrm{O}\right), 629 v(\mathrm{M}-\mathrm{N}), 486 v(\mathrm{M}-\mathrm{O})$. Anal. Calcd. $\mathrm{C}_{46} \mathrm{H}_{42} \mathrm{~N}_{8} \mathrm{O}_{8} \mathrm{~S}_{2} \mathrm{Mn}(1003.19 \mathrm{~g} / \mathrm{mol})$ : C $55.02 \%, \mathrm{H} 3.62 \%, \mathrm{~N} 16.75 \%$, Found: $\mathrm{C} 54.78 \%$, H $3.51 \%, \mathrm{~N} 16.41 \%$.

3.3.6. Bis(4-benzoyl-3-methyl-1-phenyl-2-pyrazolin-5-one dinitrophenylhydrazone) Diaquacobalt(Ii) Monohydrate $\mathrm{Co}(\mathrm{Bmpp}-\mathrm{Dh})_{2}\left(\mathrm{H}_{2} \mathrm{O}\right)_{2} \cdot \mathrm{H}_{2} \mathrm{O}$

Yield: $72 \%$. M.p.: $248-250{ }^{\circ} \mathrm{C}$. Molar cond. $\left(10^{-3} \mathrm{M}\right.$ in DMF): $10.91 \mathrm{ohm}^{-1} \mathrm{~cm}^{2} \mathrm{~mol}^{-1} \cdot \mu_{\text {eff }}$ (B.M.): 4.48. UV-VIS (DMF) $\lambda_{\max } \mathrm{nm}: 271\left(\pi \rightarrow \pi^{*}\right), 323\left(\mathrm{n} \rightarrow \pi^{*}\right), 425,460(\mathrm{~d} \rightarrow \mathrm{d}) . \quad \mathrm{IR}\left(\mathrm{KBr}, \mathrm{cm}^{-1}\right): 3484$ 
$v(\mathrm{~N}-\mathrm{H}), 3396 v(\mathrm{O}-\mathrm{H}), 2926 v(\mathrm{C}-\mathrm{H}), 1620 v(\mathrm{C}=\mathrm{N}), 832 v\left(\mathrm{H}_{2} \mathrm{O}\right), 622 v(\mathrm{M}-\mathrm{N}), 487 v(\mathrm{M}-\mathrm{O})$. Anal. Calcd. $\mathrm{C}_{46} \mathrm{H}_{38} \mathrm{~N}_{12} \mathrm{O}_{13} \mathrm{Co}(1025.20 \mathrm{~g} / \mathrm{mol}):$ C $53.84 \%$, H 3.74\%, N 16.39\%, Found: C 53.40\%, H 3.92\%, N 16.22\%.

3.3.7. Bis(4-benzoyl-3-methyl-1-phenyl-2-pyrazolin-5-one dinitrophenylhydrazone) Diaquanickel(Ii) Monohydrate $\mathrm{Ni}(\mathrm{Bmpp}-\mathrm{Dh})_{2}\left(\mathrm{H}_{2} \mathrm{O}\right)_{2} \cdot \mathrm{H}_{2} \mathrm{O}$

Yield: $72 \%$. M.p.: $247-249^{\circ} \mathrm{C}$. Molar cond. $\left(10^{-3} \mathrm{M}\right.$ in DMF): $6.34 \mathrm{ohm}^{-1} \mathrm{~cm}^{2} \mathrm{~mol}^{-1}$. $\mu_{\text {eff }}$ (B.M.): 2.90. UV-VIS (DMF) $\lambda_{\max } \mathrm{nm}: 274\left(\pi \rightarrow \pi^{*}\right), 324\left(\mathrm{n} \rightarrow \pi^{*}\right), 431,463(\mathrm{~d} \rightarrow \mathrm{d})$. IR $\left(\mathrm{KBr}, \mathrm{cm}^{-1}\right): 3494$ $v(\mathrm{~N}-\mathrm{H}), 3394 v(\mathrm{O}-\mathrm{H}), 2925 v(\mathrm{C}-\mathrm{H}), 1619 v(\mathrm{C}=\mathrm{N}), 832 v\left(\mathrm{H}_{2} \mathrm{O}\right), 624 v(\mathrm{M}-\mathrm{N}), 478 v(\mathrm{M}-\mathrm{O})$. Anal. Calcd. $\mathrm{C}_{46} \mathrm{H}_{38} \mathrm{~N}_{12} \mathrm{O}_{13} \mathrm{Ni}(1024.96 \mathrm{~g} / \mathrm{mol}): \mathrm{C} 53.86 \%$, H 3.74\%, N 16.39\%, Found: C 53.68\%, H 3.80\%, N 16.32\%.

3.3.8. Bis(4-benzoyl-3-methyl-1-phenyl-2-pyrazolin-5-one dinitrophenylhydrazone) Diaquacopper(Ii) Dihydrate $\mathrm{Cu}(\mathrm{Bmpp}-\mathrm{Dh})_{2}\left(\mathrm{H}_{2} \mathrm{O}\right)_{2} \cdot 2 \mathrm{H}_{2} \mathrm{O}$

Yield: $79 \%$. M.p.: $250-251^{\circ} \mathrm{C}$. Molar cond. $\left(10^{-3} \mathrm{M}\right.$ in DMF): $9.96 \mathrm{ohm}^{-1} \mathrm{~cm}^{2} \mathrm{~mol}^{-1} \cdot \mu_{\text {eff }}$ (B.M.): 1.95. UV-VIS (DMF) $\lambda_{\max } \mathrm{nm}: 268\left(\pi \rightarrow \pi^{*}\right), 324\left(\mathrm{n} \rightarrow \pi^{*}\right), 426,449(\mathrm{~d} \rightarrow \mathrm{d}) . \quad \mathrm{IR}\left(\mathrm{KBr}, \mathrm{cm}^{-1}\right): 3493$ $v(\mathrm{~N}-\mathrm{H}), 3396 v(\mathrm{O}-\mathrm{H}), 2930 v(\mathrm{C}-\mathrm{H}), 1619 v(\mathrm{C}=\mathrm{N}), 830 v\left(\mathrm{H}_{2} \mathrm{O}\right), 623 v(\mathrm{M}-\mathrm{N}), 487 v(\mathrm{M}-\mathrm{O})$. Anal. Calcd. $\mathrm{C}_{46} \mathrm{H}_{40} \mathrm{~N}_{12} \mathrm{O}_{14} \mathrm{Cu}(1047.82 \mathrm{~g} / \mathrm{mol}):$ C 52.68\%, H 3.89\%, N 16.04\%, Found: C 52.65\%, H 3.75\%, N 15.83\%.

3.3.9. Bis(4-benzoyl-3-methyl-1-phenyl-2-pyrazolin-5-one phenylhydrazone) Diaquamanganese (Ii) Dihydrate $\mathrm{Mn}(\mathrm{Bmpp}-\mathrm{Ph})_{2}\left(\mathrm{H}_{2} \mathrm{O}\right)_{2} \cdot 2 \mathrm{H}_{2} \mathrm{O}$

Yield: $73 \%$. M.p.: $120-121^{\circ} \mathrm{C}$. Molar cond. $\left(10^{-3} \mathrm{M}\right.$ in DMF): $8.28 \mathrm{ohm}^{-1} \mathrm{~cm}^{2} \mathrm{~mol}^{-1}$. $\mu_{\text {eff }}$ (B.M.): 5.63. UV-VIS (DMF) $\lambda_{\max } \mathrm{nm}: 228\left(\pi \rightarrow \pi^{*}\right), 303\left(\mathrm{n} \rightarrow \pi^{*}\right), 393(\mathrm{~d} \rightarrow \mathrm{d}) . \mathrm{IR}\left(\mathrm{KBr}, \mathrm{cm}^{-1}\right): 3492 v(\mathrm{~N}-\mathrm{H}), 3397$ $v(\mathrm{O}-\mathrm{H}), 2943 v(\mathrm{C}-\mathrm{H}), 1621 v(\mathrm{C}=\mathrm{N}), 841 v\left(\mathrm{H}_{2} \mathrm{O}\right), 631 v(\mathrm{M}-\mathrm{N}), 486 v(\mathrm{M}-\mathrm{O})$. Elemental analysis for $\mathrm{C}_{46} \mathrm{H}_{46} \mathrm{~N}_{8} \mathrm{O}_{6} \mathrm{Mn}(\%)$ : found C 64.00, H 5.53, N 13.07; calculated C 64.09, H 5.38, N 13.01, Mol. mass (g/mol): 861.29.

3.3.10. Bis(4-benzoyl-3-methyl-1-phenyl-2-pyrazolin-5-one phenylhydrazone) Diaquacobalt(Ii) Monohydrate $\mathrm{Co}(\mathrm{Bmpp}-\mathrm{Ph})_{2}\left(\mathrm{H}_{2} \mathrm{O}\right)_{2} \cdot \mathrm{H}_{2} \mathrm{O}$

Yield: $72 \%$. M.p.: $125-127^{\circ} \mathrm{C}$. Molar cond. $\left(10^{-3} \mathrm{M}\right.$ in DMF): $10.02 \mathrm{ohm}^{-1} \mathrm{~cm}^{2} \mathrm{~mol}^{-1}$. $\mu_{\text {eff }}$ (B.M.): 4.45. UV-VIS (DMF) $\lambda_{\max } \mathrm{nm}: 230\left(\pi \rightarrow \pi^{*}\right), 317\left(\mathrm{n} \rightarrow \pi^{*}\right), 554,627,708(\mathrm{~d} \rightarrow \mathrm{d}) . \mathrm{IR}\left(\mathrm{KBr}, \mathrm{cm}^{-1}\right): 3480$ $v(\mathrm{~N}-\mathrm{H}), 3373 v(\mathrm{O}-\mathrm{H}), 2949 v(\mathrm{C}-\mathrm{H}), 1618 v(\mathrm{C}=\mathrm{N}), 826 v\left(\mathrm{H}_{2} \mathrm{O}\right), 641 v(\mathrm{M}-\mathrm{N}), 485 v(\mathrm{M}-\mathrm{O})$. Elemental analysis for $\mathrm{C}_{46} \mathrm{H}_{44} \mathrm{~N}_{8} \mathrm{O}_{5} \mathrm{Co}(\%)$ : found $\mathrm{C} 65.06, \mathrm{H} 4.96, \mathrm{~N} 13.14$; calculated C 65.15, H 5.23, N 13.22, Mol. mass (g/mol): 847.28.

3.3.11. Bis(4-benzoyl-3-methyl-1-phenyl-2-pyrazolin-5-one phenylhydrazone) Diaquanickel(Ii) Dihydrate $\mathrm{Ni}(\mathrm{Bmpp}-\mathrm{Ph})_{2}\left(\mathrm{H}_{2} \mathrm{O}\right)_{2} \cdot 2 \mathrm{H}_{2} \mathrm{O}$

Yield: $72 \%$. M.p.: $213-215^{\circ} \mathrm{C}$. Molar cond. $\left(10^{-3} \mathrm{M}\right.$ in DMF): $11.43 \mathrm{ohm}^{-1} \mathrm{~cm}^{2} \mathrm{~mol}^{-1}$. $\mu_{\text {eff }}($ B.M. $)$ : 2.94. UV-VIS (DMF) $\lambda_{\max } \mathrm{nm}: 232\left(\pi \rightarrow \pi^{*}\right), 309\left(\mathrm{n} \rightarrow \pi^{*}\right), 678,808(\mathrm{~d} \rightarrow \mathrm{d}) . \mathrm{IR}\left(\mathrm{KBr}, \mathrm{cm}^{-1}\right): 3487 v(\mathrm{~N}-\mathrm{H})$, $3393 v(\mathrm{O}-\mathrm{H}), 2935 v(\mathrm{C}-\mathrm{H}), 1619 v(\mathrm{C}=\mathrm{N}), 845 v\left(\mathrm{H}_{2} \mathrm{O}\right), 639 v(\mathrm{M}-\mathrm{N}), 498 v(\mathrm{M}-\mathrm{O})$. Elemental Analysis for $\mathrm{C}_{46} \mathrm{H}_{46} \mathrm{~N}_{8} \mathrm{O}_{6} \mathrm{Ni}$ (\%): found C 63.80, H 5.79, N 12.18; calculated C 63.81, H 5.36, N 12.95, Mol. mass (g/mol): 865.05.

3.3.12. Bis(4-benzoyl-3-methyl-1-phenyl-2-pyrazolin-5-one phenylhydrazone) Diaquacopper(Ii) Dihydrate $\mathrm{Cu}(\mathrm{Bmpp}-\mathrm{Ph})_{2}\left(\mathrm{H}_{2} \mathrm{O}\right)_{2} \cdot \mathrm{H}_{2} \mathrm{O}$

Yield: $80 \%$. M.p.: $195-197^{\circ} \mathrm{C}$. Molar cond. $\left(10^{-3} \mathrm{M}\right.$ in DMF): $5.98 \mathrm{ohm}^{-1} \mathrm{~cm}^{2} \mathrm{~mol}^{-1}$. $\mu_{\text {eff }}($ B.M.): 1.94.UV-VIS (DMF) $\lambda_{\max } \mathrm{nm:} 215\left(\pi \rightarrow \pi^{*}\right), 304,317\left(\mathrm{n} \rightarrow \pi^{*}\right), 516,(\mathrm{~d} \rightarrow \mathrm{d}) . \mathrm{IR}\left(\mathrm{KBr}, \mathrm{cm}^{-1}\right): 3483 v(\mathrm{~N}-\mathrm{H})$, $3378 v(\mathrm{O}-\mathrm{H}), 2923 v(\mathrm{C}-\mathrm{H}), 1618 v(\mathrm{C}=\mathrm{N}), 848 v\left(\mathrm{H}_{2} \mathrm{O}\right), 627 v(\mathrm{M}-\mathrm{N}), 482 v(\mathrm{M}-\mathrm{O})$. Elemental analysis for $\mathrm{C}_{46} \mathrm{H}_{46} \mathrm{~N}_{8} \mathrm{O}_{6} \mathrm{Cu}(\%)$ : found C 64.76, H 5.02, N 13.13; calculated C 64.80, H 5.21, N 13.15, Mol. mass: (g/mol): 851.89 . 
3.3.13. Bis(4-acetyl-3-methyl-1-phenyl-2-pyrazolin-5-one phenylhydrazone) Diaquacobalt(Ii) Dihydrate $\mathrm{Co}(\mathrm{Ampp}-\mathrm{Ph})_{2}\left(\mathrm{H}_{2} \mathrm{O}\right)_{2} \cdot 2 \mathrm{H}_{2} \mathrm{O}$

Yield: $75 \%$. M.p.: $160-162{ }^{\circ} \mathrm{C}$. Molar cond. $\left(10^{-3} \mathrm{M}\right.$ in DMF): $6.78 \mathrm{ohm}^{-1} \mathrm{~cm}^{2} \mathrm{~mol}^{-1}$. $\mu_{\text {eff }}$ (B.M.): 4.49.UV-VIS (DMF) $\lambda \max \mathrm{nm}: 223\left(\pi \rightarrow \pi^{*}\right), 313,324\left(\mathrm{n} \rightarrow \pi^{*}\right), 390,536,600(\mathrm{~d} \rightarrow \mathrm{d}) . \mathrm{IR}\left(\mathrm{KBr}, \mathrm{cm}^{-1}\right): 3485$ $v(\mathrm{~N}-\mathrm{H}), 3391 v(\mathrm{O}-\mathrm{H}), 2923 v(\mathrm{C}-\mathrm{H}), 1619 v(\mathrm{C}=\mathrm{N}), 844 v\left(\mathrm{H}_{2} \mathrm{O}\right), 621 v(\mathrm{M}-\mathrm{N}), 489 v(\mathrm{M}-\mathrm{O})$. Elemental analysis for $\mathrm{C}_{36} \mathrm{H}_{42} \mathrm{~N}_{8} \mathrm{O}_{6} \mathrm{Co}$ (\%): found C 57.95, H 5.63, N 15.40; calculated C 58.28, H 5.71, N 15.11, Mol. mass (g/mol): 741.25.

3.3.14. Bis(4-acetyl-3-methyl-1-phenyl-2-pyrazolin-5-one phenylhydrazone) Diaquacopper(Ii) $\mathrm{Cu}(\mathrm{Ampp}-\mathrm{Ph})_{2}\left(\mathrm{H}_{2} \mathrm{O}\right)_{2}$

Yield: $79 \%$. M.p.: $212-213{ }^{\circ} \mathrm{C}$. Molar cond. $\left(10^{-3} \mathrm{M}\right.$ in DMF): $12.05 \mathrm{ohm}^{-1} \mathrm{~cm}^{2} \mathrm{~mol}^{-1}$. $\mu_{\text {eff }}$ (B.M.): 1.93. UV-VIS (DMF) $\lambda_{\max } \mathrm{nm:} 217\left(\pi \rightarrow \pi^{*}\right), 310,323\left(\mathrm{n} \rightarrow \pi^{*}\right), 401,594(\mathrm{~d} \rightarrow \mathrm{d}) . \mathrm{IR}\left(\mathrm{KBr}, \mathrm{cm}^{-1}\right): 3493$ $v(\mathrm{~N}-\mathrm{H}), 3399 v(\mathrm{O}-\mathrm{H}), 2926 v(\mathrm{C}-\mathrm{H}), 1618 v(\mathrm{C}=\mathrm{N}), 821 v\left(\mathrm{H}_{2} \mathrm{O}\right), 628 v(\mathrm{M}-\mathrm{N}), 478 v(\mathrm{M}-\mathrm{O})$. Elemental Analysis for $\mathrm{C}_{36} \mathrm{H}_{38} \mathrm{~N}_{8} \mathrm{O}_{4} \mathrm{Cu}(\%)$ : found C 60.49, $\mathrm{H}$ 5.11, N 15.40; calculated C 60.86, H 5.40, N 15.78, Mol. mass (g/mol): 709.85.

\subsection{X-ray Diffraction Study of Ampp-Ph}

Single crystal X-ray diffraction studies were performed at $200 \mathrm{~K}$ using a Bruker Kappa Apex II diffractometer with graphite monochromator, Mo K $\alpha$ radiation $(\lambda=0.71073 \AA)$. Data collection was carried out with the help of the APEXII while SAINT was used for cell refinement and data reduction [46]. The structure was solved using SHELXS-2014 [47] and refined by least-squares procedures using SHELXL-2014 [47] with SHELXLE [48] as a graphical interface. All non-hydrogen atoms were refined anisotropically. Carbon-bound $\mathrm{H}$ atoms were placed in calculated positions and were included in the refinement in the riding model approximation, with $U_{\text {iso }}(\mathrm{H})$ set to $1.2 U_{\text {eq }}(\mathrm{C})$. The $\mathrm{H}$ atoms of the methyl groups were allowed to rotate with a fixed angle around the $\mathrm{C}-\mathrm{C}$ bonds to best fit the experimental electron density (HFIX 137 in the SHELX program suite [47]), with $U_{\text {iso }}(\mathrm{H})$ set to $1.5 U_{\text {eq }}(\mathrm{C})$. Nitrogen-bound $\mathrm{H}$ atoms were located on a difference Fourier map and refined freely. The data were corrected for absorption effects by the numerical method using SADABS [46]. Crystallographic data for 4-acetyl-3-methyl-1-phenyl-2-pyrazoline-5-one phenylhydrazone Ampp-Ph reported herein has been deposited with the Cambridge Crystallographic Data Centre, CCDC \#. 1417242. CCDC 1417242 contains the supplementary crystallographic data which can be obtained free of charge via http://www.ccdc.cam.ac.uk/conts/retrieving.html, or from the Cambridge Crystallographic Data Centre, 12 Union Road, Cambridge CB2 IEZ, UK; Fax: +44-1223-336-033; E-mail: deposit@ccdc.cam.ac.uk.

\subsection{Antibacterial Studies}

Synthesized compounds were screened against Gram-positive Staphylococcus aureus, Bacillus pumilus, and Gram-negative Proteus vulgaris, Aeromonas hydrophila bacterial isolates using the Kirby-Bauer disc diffusion technique at a concentration of $40 \mathrm{mg} / \mathrm{mL}$ in DMSO. The antibacterial effect was taken according to the size of inhibition zones around the paper discs with slight modifications to suit experimental conditions [49]. The bacterial isolates were grown in freshly-prepared nutrient broth growth media of suitable antibacterial screening purposes. To a solidified $20 \mathrm{~mL}$ Mueller-Hinton agar in inoculation plates, $0.1 \mathrm{~mL}$ of test bacteria was spread over the medium using a sterilized spreader. Pre-sterilized filter paper disc with a diameter of $6 \mathrm{~mm}$ which have been impregnated into prepared solutions of synthesized compounds were placed in the plates ensuring a reasonable equidistance from each other to give room to avoid zones of inhibition reading interferences. A filter paper disc treated with DMSO was used as control while antibacterial chloramphenicol served as the standard drug and was used as a reference to evaluate the potency of the tested compounds maintaining the same experimental conditions. The plates were left for a few hours in the refrigerator for pre-diffusion and finally transferred to an incubator at $37^{\circ} \mathrm{C}$ for $24 \mathrm{~h}$. This procedure was performed in triplicates. 
The antibacterial activity was determined by measuring the diameter of the zones showing complete inhibition of bacterial growth across the filter paper disc in millimeters, subtracting the diameter of the filter paper disc, and finally dividing by 2 to obtain the exact zone of inhibition. The values were calculated as mean value of triplicates.

\subsection{Antioxidant (Free Radical Scavenging) Activity}

Free radical scavenging properties of the synthesized compounds were tested against the free radical of 1,1-diphenyl-2-picryl-hydrazil (DPPH), employing the method of Blois with some modifications [50]. A $0.1 \mathrm{mmol}$ solution of the DPPH in methanol was prepared, and $1 \mathrm{~mL}$ of the solution was added to $3 \mathrm{~mL}$ prepared solutions of the test compounds in a mixture of DMSO and methanol in a mole ratio of 1:9, respectively, at different concentrations $(0.13,0.25$, and $0.50 \mathrm{mg} / \mathrm{mL})$. The same procedure was carried out for ascorbic acid (reference drug) and an equal volume of dissolving solvents as control. The mixture was shaken vigorously and allowed to stand at room temperature in the dark for $30 \mathrm{~min}$. With the use of a spectrophotometer at a wavelength of $517 \mathrm{~nm}$ the absorbance of each solution was measured. The capabilities of synthesized compounds to scavenge DPPH radical were calculated using the expression;

$$
\text { Scaveging activity }(\%)=\frac{A_{0}-A_{1}}{A_{0}} \times 100
$$

where $A_{0}$ is the absorbance with control sample and $A_{1}$ is the absorbance with test samples including that of the standard drug.

\section{Conclusions}

A new set of acylpyrazolone phenylhydrazones, their transition metal complexes inclusive, have been successfully prepared, adequately identified, and contributed to the pull of compounds with unique properties that are potential antimicrobial agents, which may become an alternative replacement for disease-resistant therapeutic agents. The structural elucidation, as well as proposed molecular structures of these ligands based on analytical, NMR, and mass spectroscopy results, is in agreement with the single crystal structure of their 4-benzoyl-3-methyl-1-phenyl-2-pyrazolin-5-one phenylhydrazone reported earlier. Their metal complexes have mostly exhibited unprecedented electronic spectra associated with proposed transitions, but they have shown expected magnetic properties which have been used alongside their FTIR and thermogravimetric analysis (TGA) results to justify their proposed structures. The compounds have shown generally low antibacterial properties, but good antioxidant activity, with the metal complexes having a better bioactivity overall.

Acknowledgments: The financial support of the National Research Foundation (NRF)/Sasol Inzalo Foundation (SIF) and Govan Mbeki Research and Development Centre (GMRDC), University of Fort Hare is appreciated. Idemudia OG, thank the NRF/SIF for the award of a PDF (Grant UID: 92275).

Author Contributions: The research project was conceived by Omoruyi G. Idemudia and Alexander P. Sadimenko. Omoruyi G. Idemudia designed, developed methods, carried out synthesis and performed the experiments, interpreted analytical data/results as well as wrote/prepared manuscript. Eric C. Hosten performed X-ray crystal diffraction and contributed to the discussion of crystal structure.

Conflicts of Interest: The authors declare no conflict of interest.
Abbreviations
DMF Dimethylformamide
DTG Thermogravimetric derivative
DPPH 1,1-diphenyl-2-picryl-hydrazil
DMSO Dimethylsulfoxide
TLC Thin Layer Chromatography 


\section{References}

1. Cozzi, P.G. Metal-Salen Schiff base complexes in catalysis: Practical aspects. Chem. Soc. Rev. 2004, 33, 410-421. [CrossRef] [PubMed]

2. Singh, L.P.; Bhatnagar, J.M. Copper(II) selective electrochemical sensor based on Schiff base complexes. Talanta 2004, 64, 313-319. [CrossRef] [PubMed]

3. Jeong, T.; Lee, H.K.; Jeong, D.C.; Jeon, S. A lead (II)-selective PVC membrane based on a Schiff base complex of N,N-bis(salicylidene)-2,6-pyridinediamine. Talanta 2005, 65, 543-548. [CrossRef] [PubMed]

4. Avaji, P.G.; Kumar, C.H.V.; Patil, S.A.; Shivananda, K.N.; Nagaraju, C. Synthesis, spectral characterization, in vitro microbiological evaluation and cytotoxic activities of novel macrocyclic bis hydrazone. Eur. J. Med. Chem. 2009, 44, 3552-3559. [CrossRef] [PubMed]

5. Puthilibai, G.; Vasudevan, S.; Rani, S.K.; Rajagopal, G. Synthesis, spectroscopic characterization, electrochemical behaviour and antibacterial activity of $\mathrm{Ru}(\mathrm{III})$ complexes of 2-[(4-N,N-dimethylaminophenylimino)-methyl]4-halophenol. Spectrochim. Acta Part A: Mol. Biomol. Spect. 2009, 72, 796-800. [CrossRef] [PubMed]

6. Kulkarni, A.; Avaji, P.G.; Bagihalli, G.B.; Patil, S.A.; Badami, P.S. Synthesis, spectral, electrochemical and biological studies of $\mathrm{Co}(\mathrm{II}), \mathrm{Ni}(\mathrm{II})$ and $\mathrm{Cu}(\mathrm{II})$ complexes with Schiff bases of 8-formyl-7-hydroxy-4-methyl coumarin. J. Coord. Chem. 2009, 62, 481-492. [CrossRef]

7. Shiri-Yekta, Z.; Yaftian, M.R. Anion control selectivity of neutral N4-type schiff base extractants towards transition metal ions. Iran. J. Chem. Chem. Eng. 2010, 29, 11-17.

8. Gupta, K.C.; Sutar, A.K. Catalytic activities of Schiff base transition metal complexes. Coord. Chem. Rev. 2008, 252, 1420-1450. [CrossRef]

9. Kumar, R.; Mani, G. Exhibition of the Brønsted acid-base character of a Schiff base in palladium(II) complex formation: Lithium complexation, fluxional properties and catalysis of Suzuki reactions in water. Dalton Trans. 2015. [CrossRef] [PubMed]

10. Nejati, K.; Rezvani, Z.; Massoumi, B. Syntheses and investigation of thermal properties of copper complexes with azo-containing Schiff-base dyes. Dyes Pigments 2007, 75, 653-657. [CrossRef]

11. Ebenso, E.E.; Isabirye, D.A.; Eddy, N.O. Adsorption and quantum chemical studies on the inhibition potentials of some thiosemicarbazides for the corrosion of mild steel in acidic medium. Int. J. Mol. Sci. 2010, 11, 2473-2498. [CrossRef] [PubMed]

12. Gomez, B.; Likhanova, N.V.; Aguilar, M.A.D.; Palou, R.M.; Vela, A.; Gasquez, J.L. Quantum chemical study of the inhibitive properties of 2-pyridyl-azoles. J. Phys. Chem. 2006, B110, 8928-8934. [CrossRef] [PubMed]

13. Finsgar, M.; Lesar, A.; Kokaij, A.; Milosev, I. A comparative electrochemical and quantum chemical calculation study of BTAH and BTAOH as copper corrosion inhibitors in near neutral chloride solution. Electrochim. Acta 2008, 53, 8287-8297. [CrossRef]

14. Cinarli, A.; Gürbüz, D.; Tavman, A.; Birteksöz, A.S. Synthesis, spectra characterization and antimicrobial activity of some Schiff bases of 4-chloro-2-aminophenol. Bull. Chem. Soc. Ethiop. 2011, 25, 407-417. [CrossRef]

15. Kajal, A.; Bala, S.; Kamboj, S.; Sharma, N.; Saini, V. Schiff bases: A versatile pharmacophore. J. Catal. 2013. [CrossRef]

16. Vashi, K.; Naik, H.B. Synthesis of novel Schiff base and azetidinone derivatives and their antibacterial activity. Eur. J. Chem. 2004, 1, 272-276. [CrossRef]

17. Marchetti, F.; Pettinari, C.; Pettinari, R. Acylpyrazolone ligands: Synthesis, structures, metal coordination chemistry and applications. Coord. Chem. Rev. 2005, 249, 2909-2945. [CrossRef]

18. Mariappan, G.; Saha, B.P.; Sutharson, L.; Ankits, G.; Pandey, L.; Kumar, D. The diverse pharmacological importance of pyrazolone derivatives: A Review. J. Pharm. Res. 2010, 3, 2856-2859.

19. Abdel-Aziz, H.A.; Mekawey, A.A.; Dawood, K.M. Convenient synthesis and antimicrobial evaluation of some novel 2-substituted-3-methylbenzofuran derivatives. Eur. J. Med. Chem. 2009, 44, 3637-3644. [CrossRef] [PubMed]

20. Przybylski, P.; Huczynski, A.; Pyta, K.; Brzezinski, B.; Bartl, F. Biological properties of schiff bases and azo derivatives of phenols. Curr. Org. Chem. 2009, 13, 124-148. [CrossRef]

21. Idemudia, O.G.; Sadimenko, A.P.; Afolayan, A.J.; Hosten, E.C. 3-Methyl-1-phenyl-4-[(phenyl) (2-phenylhydrazin-1-yl)methylidene]-1H-pyrazol-5(4H)-one. Acta Cryst. 2012, E68, o1280-o1281. [CrossRef] [PubMed] 
22. Idemudia, O.G.; Sadimenko, A.P.; Hosten, E.C. Crystal structure of 4-propyl-3-methyl-1-phenyl2-pyrazolin-5-one thiosemicarbazone $\mathrm{C}_{15} \mathrm{H}_{19} \mathrm{~N}_{5} \mathrm{OS}$. Z. Kristallogr. NCS 2015, 230, 81-82. [CrossRef]

23. Brady, O.L.; Elsmie, G.V. The use of 2,4-dinitrophenylhydrazine as a reagent for aldehydes and ketones. Analyst 1926, 51, 77-78. [CrossRef]

24. Idemudia, O.G.; Sadimenko, A.P.; Hosten, E.C. 4-\{[2-(2,4-Dinitrophenyl) hydrazinylidene] (phenyl)methyl\}5-methyl-2-phenyl-1H-pyrazol-3(2H)-one ethanol monosolvate. Acta Cryst. 2012, E68. [CrossRef] [PubMed]

25. Idemudia, O.G.; Sadimenko, A.P.; Afolayan, A.J. Potential therapeutic $\mathrm{Mn}^{2+}$ and $\mathrm{Ni}^{2+}$ complexes of new 4-acetyl-3-methyl-1-phenyl-2-pyrazoline-5-one phenylhydrazone Ampp-Ph. Macromol. Symp. 2015, 351, 61-68. [CrossRef]

26. Geary, W.J. The use of conductivity measurements in organic solvents for the characterization of coordination compounds. Coord. Chem. Rev. 1971, 7, 81-122. [CrossRef]

27. Jadeja, R.N.; Parihar, S.; Vyas, K.; Gupta, V.K. Synthesis and crystal structure of a series of pyrazolone based Schiff base ligands and DNA binding studies of their copper complexes. J. Mol. Struct. 2012, 1013, 86-94. [CrossRef]

28. Idemudia, O.G.; Sadimenko, A.P.; Afolayan, A.J.; Hosten, E.C. Synthesis and characterization of bioactive acylpyrazolone sulfanilamides and their transition metal complexes: Single crystal structure of 4-Benzoyl-3-methyl-1-phenyl-2-pyrazolin-5-one Sulfanilamide. Bioinorg. Chem. Appl. 2015. [CrossRef] [PubMed]

29. Dolaz, M.; McKee, V.; Golcu, A.; Tumer, M. Synthesis, structural characterization, spectroscopic and electrochemical studies of $N, N$-bis[(2,4-dimethoxyphenyl) methylidene]butane-1,4-diamine. Curr. Org. Chem. 2010, 14, 281-288. [CrossRef]

30. Bernstein, J.; Davis, R.E.; Shimoni, L.; Chang, N.-L. Patterns in hydrogen bonding: Functionality and graph set analysis in crystals. Angew. Chem. Int. Ed. Engl. 1995, 34, 1555-1573. [CrossRef]

31. Etter, M.C.; MacDonald, J.C.; Bernstein, J. Graph-set analysis of hydrogen-bond patterns in organic crystals. Acta Crystallogr. 1990, B46, 256-262. [CrossRef]

32. Maurya, R.C.; Pandey, A.; Chaurasia, J.; Martin, H. Metal nitrosyl complexes of bioinorganic, catalytic, and environmental relevance: A novel single-step synthesis of dinitrosylmolybdenum( $(0)$ complexes of $\left\{\mathrm{Mo}(\mathrm{NO})_{2}\right\}^{6}$ electron configuration involving Schiff bases derived from 4-acyl-3-methyl-1phenyl-2-pyrazolin-5-one and 4-aminoantipyrine, directly from molybdate(VI) and their characterization. J. Mol. Struct. 2006, 798, 89-101.

33. Nakamato, K. Infrared and Raman Spectra of Inorganic and Coordination Compounds, 5th ed.; Wiley-Interscience: New York, NY, USA, 1979.

34. Yang, Z.-Y.; Yang, R.-D.; Li, F.-S.; Yu, K.-B. Crystal structure and antitumor activity of some rare earth metal complexes with Schiff base. Polyhedron 2000, 19, 2599-2604. [CrossRef]

35. Liu, J.; Zhang, B.; Bowan, W.U.; Zhang, K.; Shenli, H.U. The direct electrochemical synthesis of Ti(II), Fe(II), $\mathrm{Cd}(\mathrm{II}), \mathrm{Sn}(\mathrm{II})$, and $\mathrm{Pb}(\mathrm{II})$ complexes with $N, N$-bis(Salicylidene)-ophenylenediamine. Turkish J. Chem. 2007, 31, 623-629.

36. Naeimi, H.; Moradian, M. Synthesis and characterization of nitro-Schiff bases derived from 5-nitro-salicylaldehyde and various diamines and their complexes of Co(II). J. Coord. Chem. 2010, 63, 156-162. [CrossRef]

37. West, D.X.; Lockwood, M.A.; Liberta, A.E.; Chen, X.; Willett, R.D. Spectral nature, antifungal activity and molecular structure of metal complexes of acetylpyrazine N4-substituted thiosemicarbazones. Transit. Met. Chem. 1993, 18, 221-227. [CrossRef]

38. Inada, Y.; Sugimoto, K.I.; Ozutsumi, K.; Funahashi, S. Solvation structures of manganese(II), iron(II), cobalt(II), nickel(II), copper(II), zinc(II), cadmium(II), and indium(III) ions in 1,1,3,3-tetramethylurea as studied by EXAFS and electronic spectroscopy. Variation of coordination number. Inorg. Chem. 1994, 33, 1875-1880. [CrossRef]

39. Bayri, A.; Karakaplan, M. Theoretical approach to the magnetic properties of $\mathrm{Mn}(\mathrm{II}), \mathrm{Cr}(\mathrm{III})$, and $\mathrm{Cu}(\mathrm{II})$ complexes in the newly reported 12- and 15-membered macrocyclic ligands. Pramana J. Phys. 2007, 69, 301-306. [CrossRef]

40. Ferenc, W.; Czapla, K.; Sarzy, J. Magnetic, thermal and spectral characterization of 2,4-dimethoxybenzoates of $\mathrm{Mn}(\mathrm{II}), \mathrm{Co}(\mathrm{II})$ and $\mathrm{Cu}(\mathrm{II})$. Ecletica Quımica 2007, 32, 7-12. [CrossRef] 
41. Dholakiya, P.P.; Patel, M.N. Preparation, magnetic, spectral, and biocidal studies of some transition metal complexes with 3,5-dibromosalicylideneaniline and neutral bidentate ligands. Synth. React. Inorg. Met.-Org. Chem. 2002, 32, 819-829. [CrossRef]

42. Sallam, S.A. Synthesis, characterization and thermal decomposition of copper(II), nickel(II) and cobalt(II) complexes of 3-amino-5-methylpyrazole Schiff bases. Trans. Met. Chem. 2005, 30, 341-351. [CrossRef]

43. Soares, R.O.A.; Echevarria, A.; Bellieny, M.S.S.; Pinho, R.T.; de Leo, R.M.M.; Seguins, W.S.; Machado, G.M.; Canto-Cavalheiro, M.M.; Leon, L.L. Evaluation of thiosemicarbazones and semicarbazones as potential agents anti-Trypanosoma cruzi. Exp. Parasit. 2011, 129, 381-387. [CrossRef] [PubMed]

44. Joshi, S.; Pawar, V.; Uma, V. Antibacterial and antioxidant properties of Mn(II), Co(II), Ni(II) and Zn(II) complex of Schiff base derived from cephalexin. Res. J. Pharm. Biol. Chem. Sci. 2001, 2, 61-70.

45. Parihar, S.; Pathan, S.; Jadeja, R.N.; Patel, A.; Gupta, V.K. Synthesis and crystal structure of an oxovanadium(IV) complex with a pyrazolone ligand and its use as a heterogeneous catalyst for the oxidation of styrene under mild conditions. Inorg. Chem. 2012, 51, 1152-1161. [CrossRef] [PubMed]

46. APEX2; SADABS; SAINT; Bruker AXS Inc.: Madison, WI, USA, 2010.

47. Sheldrick, G.M. A short history of SHELX. Acta Crystallogr. 2008, A64, 112-122. [CrossRef] [PubMed]

48. Hubschle, C.B.; Sheldrick, G.M.; Dittrich, B. ShelXle: A Qt graphical user interface for SHELXL. J. Appl. Crystallogr. 2011, 44, 1281-1284. [CrossRef] [PubMed]

49. Bauer, A.W.; Kirby, W.M.; Sherris, J.C.; Turck, M. Antibiotic susceptibility testing by a standardized single disk method. Am. J. Clin Pathol. 1996, 45, 493-496.

50. Blois, M.S. Antioxidant determinations by the use of a stable free radical. Nature 1958, 26, 1199-1200. [CrossRef]

(C) 2016 by the authors; licensee MDPI, Basel, Switzerland. This article is an open access article distributed under the terms and conditions of the Creative Commons Attribution (CC-BY) license (http://creativecommons.org/licenses/by/4.0/). 